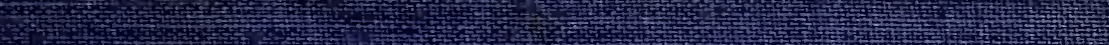



Historic, archived document

Do not assume content reflects current scientific knowledge, policies, or practices. 
105-107 GOVERNOR ST.

RICHMOND.VA.

United States

Department of

Agriculture

Aational Agricultural Hbrary

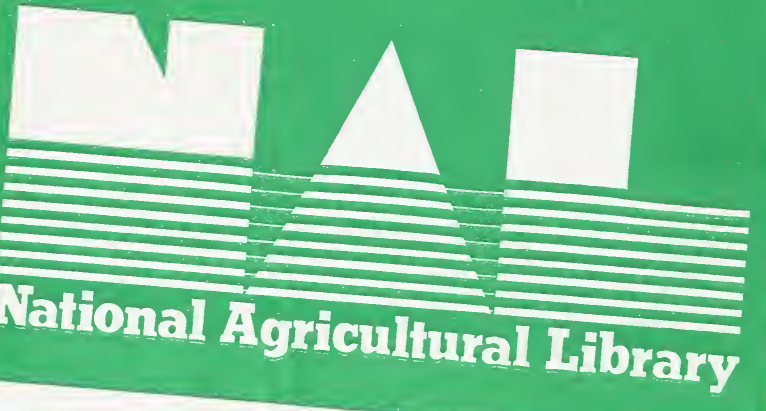




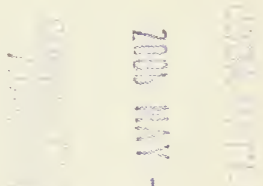

$$
\begin{aligned}
& {\left[\begin{array}{l}
1 \\
-\infty
\end{array}\right.} \\
& \begin{array}{ll}
3 \\
\xi
\end{array}
\end{aligned}
$$





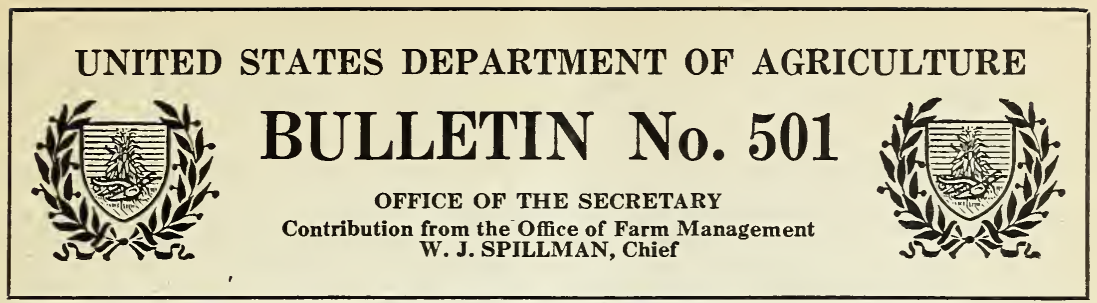

Washington, D. C.

PROFESSIONAL PAPER

February 20, 1917

\section{A STUDY IN THE COST OF PRODUCING MILK ON FOUR DAIRY FARMS, LOCATED IN WIS- CONSIN, MICHIGAN, PENNSYLVANIA, AND NORTH CAROLINA.}

By Morton O. Cooper, Scientific Assistant; C. M. Bennett, Agriculturist, and L. M. ChURCH, Assistant.

\section{CONTENTS.}

Page.

Thescope of thestudy........................
Locations and descriptions of farms where cost records were obtained...............

Methods of procuring data.................

Factors involved in the cost of producing milk.

Feed and bedding.

Labor...

Use of buildings

Use of equipment. ....................

Use of bull.

Interest.

Depreciation

1
2
4
4
4
5
10
12
12
13
13
13

Factors involved in the cost of producing milk-Continued.

Miscellaneous items................... 14

Overhead.......................... 14

Credits other than milk............... 14

Quantity of milk produced............. 16

Net cost per unit of product............ 17

Data from other sources.................. $\quad 19$

Discussion of results.................... 21

Relation of individual cow to cost of production................................ 29

Summary ............................ 33

Literature cited ...................... 34

THE SCOPE OF THE STUDY.

Concerning an enterprise so extensive as dairying, it is important that something be known of the cost of production of the principal dairy products and the economic factors affecting each. It has been found that by making a detailed study of the business on an individual farm it is possible to draw conclusions which, in a general way, hold true for other farms of the same type operating under similar conditions. By means of carefully kept cost-accounting records the Office of Farm Management has procured data on the cost of producing milk on four dairy farms of the better sort, located in separate and distinctive dairy regions, namely, those of Wisconsin, Michigan, Pennsylvania, and North Carolina. These records cover periods of from four to seven years. It is the purpose of this bulletin to outline the problem of obtaining the complete cost of producing milk on these farms and to show the relationship among the various items making up the total cost, as indicated by the data procured.

$68922^{\circ}-$ Bull. $501-17-1$ 


\section{LOCATION AND DESCRIPTION OF FARMS FROM WHICH COST RECORDS WERE OBTAINED. ${ }^{1}$}

The four farms from which data were obtained for this publication are located, respectively, in Dane County, Wis.; Macomb County, Mich.; Chester County, Pa.; and Edgecombe County, N. C. These farms will hereafter be mentioned as the "Wisconsin farm," the "Michigan farm," the "Pennsylvania farm," and the "North Carolina farm."

\section{THE WISCONSIN FARM.}

The Wisconsin farm is representative of milk production on farms where there is an abundance of pasture. This farm, consisting of 550 acres, has about 100 acres of nearly level land under cultivation, and the remainder, which is rolling and sidehill, is in pasture and woods. Most of the rolling land is too rough for cultivation, but has a naturally fertile soil which furnishes an abundant growth of grass throughout the summer months. This farm is best suited to a type of live-stock farming that provides for the profitable use of pasture. Small grain, corn, mixed hay, and alfalfa are grown in the cultivated area. Most of the corn is made into silage. These crops are all fed to live stock, and in addition some concentrates are purchased.

The dairy herd normally consists of about 50 high-grade and purebred Jersey cows, two registered bulls, and about 40 calves and young stock. The practice is to have the cows freshen during the early fall, so that the heavy production comes during the fall and winter months, when prices of butter fat are highest. Also, the increased labor required in the production of crops comes at a time when less labor is needed in the care of the dairy herd, thus providing a more uniform distribution of labor throughout the year. For four years, 1909-1912, the milk was hauled to a local creamery and sold on the butter-fat basis. The skim milk was returned to the farm and fed to the calves and pigs. The skim milk not needed for the calves has made it possible to raise 50 to 75 pigs per year. Some young stock is sold, because more is normally raised than is needed to keep up the herd.

\section{THE MICHIGAN FARM.}

The Michigan farm is an example of milk production on farms where no natural pasture land is available. This farm, containing about 195 acres, lies well and is practically all tillable land. During the summer 15 to 20 acres are used by the cows for exercise and pasture, and the remainder of the farm is devoted to the production of crops which are consumed on the farm. The whole business of the farm centers around the dairy enterprise, and practically all of the receipts

${ }^{1}$ Acknowledgment is due Mr. C. I. Brigham, of Wisconsin; Mr. Geo. A. True, of Michigan; Mr. C. G. Huey and his father, Mr. A. B. Huey, of Pennsylvania; and Mr. H. L. Brake, of North Carolina, for their hearty cooperation in furnishing the detailed reports that made this publication possible. 
are from dairy sales. The herd consists of about 50 grade and purebred Jersey cows, one or two bulls, and enough heifers to replace cows discarded and maintain the herd at the desired number. The use of a pure-bred sire and the careful selection of heifers has enabled the owner to increase the value of the herd during the record period. The cows are stall-fed the entire year, and silage has an important place in the ration. The dairy products are sold as milk, cream, and ice cream, and good prices are obtained.

\section{THE PENNSYLVANIA FARM.}

The Pennsylvania farm is within the market-milk zone of Philadelphia and is an example of the production of market milk on many diversified farms where dairying is the principal source of income. There is enough rough and rolling pasture land not suitable for cultivation to carry from 40 to 50 head of cattle. The farm contains about 200 acres of fertile and rolling land not unlike many other farms in the southeastern part of the State and the adjacent parts of Maryland. Corn, wheat, and hay are grown in a 6-year rotation. It has been found more profitable to sell wheat and a part of the hay and to buy some concentrates than to grow all the concentrates required for feed. Enough corn is put into silos to make about 200 tons of silage each year; thus the second-year corn land is cleared in time for the sowing of the first-year wheat.

The herd contains about 35 grade cows, some Holstein and others Guernsey; a pure-bred Guernsey bull, and several head of young stock. The milk is shipped in 40 -quart cans from a near-by station to a dealer in Philadelphia.

\section{THE NORTH CAROLINA FARM.}

The North Carolina farm is in the Coastal Plain region, where dairying is a comparatively new enterprise and the prices received for milk are relatively high. Feed prices, other than for cottonseed products, are also high, for most of the crop land in this region is devoted to cotton and bright-leaf tobacco, and grain and forage are not produced in quantities sufficient to supply local demand. This farm comprises about 120 acres of sandy soil, about half of which is swampy and partially covered with soft pine. The swampy woodland furnishes some pasture. About one-quarter of the crop land is devoted to cotton and tobacco, and the rest to corn, winter oats, cowpeas, and clover, most of which is fed to cows and work stock. Two feed crops can be grown each year. On most of the land more feed can be grown per acre than on any of the three northern farms, because of the longer growing season. The herd is newly established and has increased in value during the record period by the introduction of pure-bred Holstein heifers. It consists of about 20 cows. The milk until 1913 was sold by the gallon to a city dealer. During 1914 the milk was retailed. 


\section{METHODS OF PROCURING DATA.}

The data contained in this publication were procured by a system of careful cost accounting in which the owner cooperated with the Office of Farm Management. In this system each farmer sent in daily reports showing the hours of work performed by men and horses, the use made of materials, the quantities of feed consumed by the live stock, and the financial transactions, supplemented by explanatory notes. In addition to these reports, individual cow records were kept of milk, feed, and inventory values.

\section{FACTORS INVOLVED IN THE COST OF PRODUCING MILK.}

In determining the cost of producing milk it is highly important to know all the factors that must be considered and their relative importance. Indeed, one of the most important results of any costaccounting investigation is the determination of the different items of expense and their relation to the whole. This relation is of fundamental importance in efficiency studies.

For convenience in studying the results on these four farms, the items of cost are grouped under the headings "Feed and bedding," "Labor," "Use of building," "Use of equipment," "Use of bull," "Interest," "Depreciation," "Miscellaneous items," and "Orerhead." These items are summarized in Table I, and the relative importance of each is shown. The ratio between each item and the total cost of keeping a cow per year is quite uniform in different herds where methods of management are similar.

TABLE I.-Relative importance of factors which make up the cost of producing milk.

\begin{tabular}{|c|c|c|c|c|}
\hline \multirow{2}{*}{ Item. } & \multicolumn{4}{|c|}{ Actual cost per cow per year. } \\
\hline & $\begin{array}{l}\text { Wisconsin } \\
\text { farm. }\end{array}$ & $\begin{array}{l}\text { Michigan } \\
\text { farm. }\end{array}$ & $\begin{array}{c}\text { Pennsyl- } \\
\text { rania } \\
\text { farm. }\end{array}$ & $\begin{array}{l}\text { North } \\
\text { Carolina } \\
\text { farm. }\end{array}$ \\
\hline $\begin{array}{l}\text { Feed and bedding }{ }^{1} \ldots \\
\text { Labor: }\end{array}$ & $\$ 49.23$ & $\$ 71.77$ & $\$ 53.77$ & $\$ 68.06$ \\
\hline Cows and dairy. & 29.34 & 232.09 & 21. 04 & 22.63 \\
\hline $\begin{array}{l}\text { Marketing milk...... } \\
\text { Use of buildings......... }\end{array}$ & 2. 90 & $\cdots, \ldots$ & 3.72 & $\begin{array}{l}6.41 \\
6.38\end{array}$ \\
\hline $\begin{array}{l}\text { Use of buildings........... } \\
\text { Use of equipment....... }\end{array}$ & $\begin{array}{l}6.74 \\
1.28\end{array}$ & $\begin{array}{l}3.98 \\
2.61\end{array}$ & $\begin{array}{l}6.62 \\
1.45\end{array}$ & $\begin{array}{l}6.38 \\
3.22\end{array}$ \\
\hline Use of bull & 1.92 & 2. & 1.47 & 3. \\
\hline Interest... & 2.70 & 3.22 & 2. 07 & 5. \\
\hline 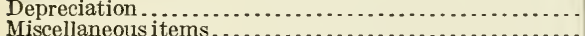 & ㅈ. & $\begin{array}{r}.99 \\
\end{array}$ & 5. 13 & $\begin{array}{l}3.52 \\
.66\end{array}$ \\
\hline $\begin{array}{l}\text { Miscellaneous items..... } \\
\text { Overhead.............. }\end{array}$ & $\begin{array}{l}2.67 \\
4.84 \\
\end{array}$ & $\begin{array}{l}1.95 \\
5.97\end{array}$ & $\begin{array}{l}2.94 \\
4.91 \\
\end{array}$ & $\begin{array}{r}.66 \\
7.64 \\
\end{array}$ \\
\hline Total... & 101.62 & 125. 45 & 103.12 & 127.76 \\
\hline
\end{tabular}

RELATION OF EACH ITEM TO TOTAL COST EXPRESSED IN PERCENTAGE.

\begin{tabular}{|c|c|c|c|c|}
\hline 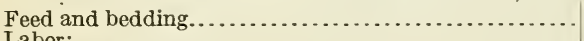 & 48.5 & 57.2 & 52.1 & 53.2 \\
\hline $\begin{array}{l}\text { Labor: } \\
\text { Cows and dairy . ....... }\end{array}$ & 28.9 & 225.6 & 20.4 & 17.8 \\
\hline Marketing milk. & 2.8 & $\ldots . . .$. & $\begin{array}{r}20.4 \\
3.6\end{array}$ & 5.0 \\
\hline 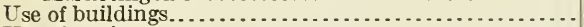 & 6. 6 & 3.2 & 6.4 & 5.0 \\
\hline 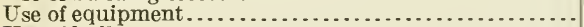 & 1.3 & 2.1 & 1. 4 & 2.5 \\
\hline 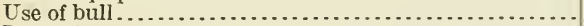 & 1.9 & 2.3 & 1.4 & 2.8 \\
\hline 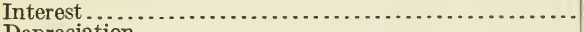 & 2.7 & 2.6 & 2.0 & 4.5 \\
\hline 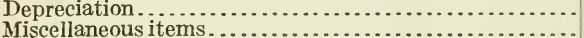 & $\ddot{2} . \ddot{6}$ & 1.5 & $\begin{array}{l}5.0 \\
2.9\end{array}$ & $\begin{array}{r}2.8 \\
.5\end{array}$ \\
\hline Overhead . . . . . . . . . . . . . . . & 4. 7 & 4. 7 & 4. 8 & 5. 9 \\
\hline Total. & 100.0 & 100.0 & 100.0 & 100.0 \\
\hline
\end{tabular}

1 On these farms part of the bedding was refuse from the mangers, thus it was necessary to consider feed and bedding as one itent.

2 Includes labor for marketing products. 
The variation in numbers of cows in each herd is eliminated by reducing the costs to the cow basis. All cows in each herd, whether milking the full year or not, were considered on the basis of days fed in making the yearly average number of cows. The average number of cows for different years in each herd whose records are considered in compiling the various tables of results per cow are shown in Table II.

TABLE II.-Size of herds on the four farms, by years.

\begin{tabular}{|c|c|c|c|c|}
\hline Year. & $\begin{array}{l}\text { Wisconsin } \\
\text { farm. }\end{array}$ & $\begin{array}{l}\text { Michigan } \\
\text { farm. }\end{array}$ & $\begin{array}{l}\text { Pennsyl- } \\
\text { vania } \\
\text { farm. }\end{array}$ & $\begin{array}{l}\text { North } \\
\text { Carolina } \\
\text { farm. }\end{array}$ \\
\hline 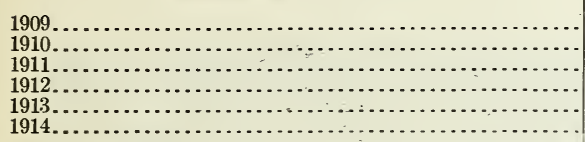 & $\begin{array}{l}49.50 \\
43.00 \\
44.43 \\
45.45\end{array}$ & $\begin{array}{l}58.00 \\
52.81 \\
49.80 \\
46.30\end{array}$ & $\begin{array}{l}36.58 \\
31.75 \\
38.44 \\
36.70\end{array}$ & $\begin{array}{l}16.38 \\
14.17 \\
12.67 \\
15.50 \\
18.75 \\
20.60\end{array}$ \\
\hline Average... & 45.60 & 51.73 & 35.87 & 16.35 \\
\hline
\end{tabular}

FEED AND BEDDING.

On all the farms the most important of the cost items in the production of milk is the expense for feed. In fact, this item is of such proportions that it is often used alone in connection with value of products in studying the relative profitableness of individual cows in the same herd. Frequently the mistake is made, in the absence of the full consideration of all the factors of cost, of figuring as net profit the difference between milk receipts and feed cost. On the Wisconsin, North Carolina, and Pennsylvania farms the feed is approximately one-half of the total cost. On the Michigan farm this item is 57.2 per cent of total cost. The difference is caused by a difference in method of feeding. The first three herds depend largely upon pasture for summer feed, while the fourth is stall-fed throughout the year.

In connection with this point it may be of interest to examine the feeding practice on each of the four farms. A word regarding feed costs is important for the purpose of showing how they were determined. Farm-grown feeds were charged to the cows at farm value, which varied somewhat with the locality and quality. All purchased feeds were charged at actual cost, the hauling being included in the charge for labor. ${ }^{1}$ Pasture was valued at the customary rate in each locality. Any charges for bedding are included with feeds under the heading of dry roughage. For the most part, however, the bedding consisted of refuse from the mangers, supplemented with straw and spoiled fodder, which had little or no value above the labor of hauling. The actual quantity for which a charge is made is so small on these farms that it is questionable whether bedding need be considered in the heading with feed.

\footnotetext{
II should be observed that these costs were obtained prior to 1915, and in making application of these figures due allowance should be made for variations in the cost of feed, etc.
} 
THE WISCONSIN FARM.

Table III gives a summary of the quantity and cost of feed consumed per cow by the Wisconsin herd for the years 1909 to 1912. The actual cost of feed and bedding varied but little from year to year. However, there was a gradual and distinct change in the feeding methods. The concentrates were usually fed in the form of a mixture. The principal feeds in the mixture were in the proportions of six parts corn, three parts bran, one part each of oil meal, cottonseed meal, and gluten feed. In 1909 each cow averaged nearly 1 ton of concentrates. This was decreased during each succeeding

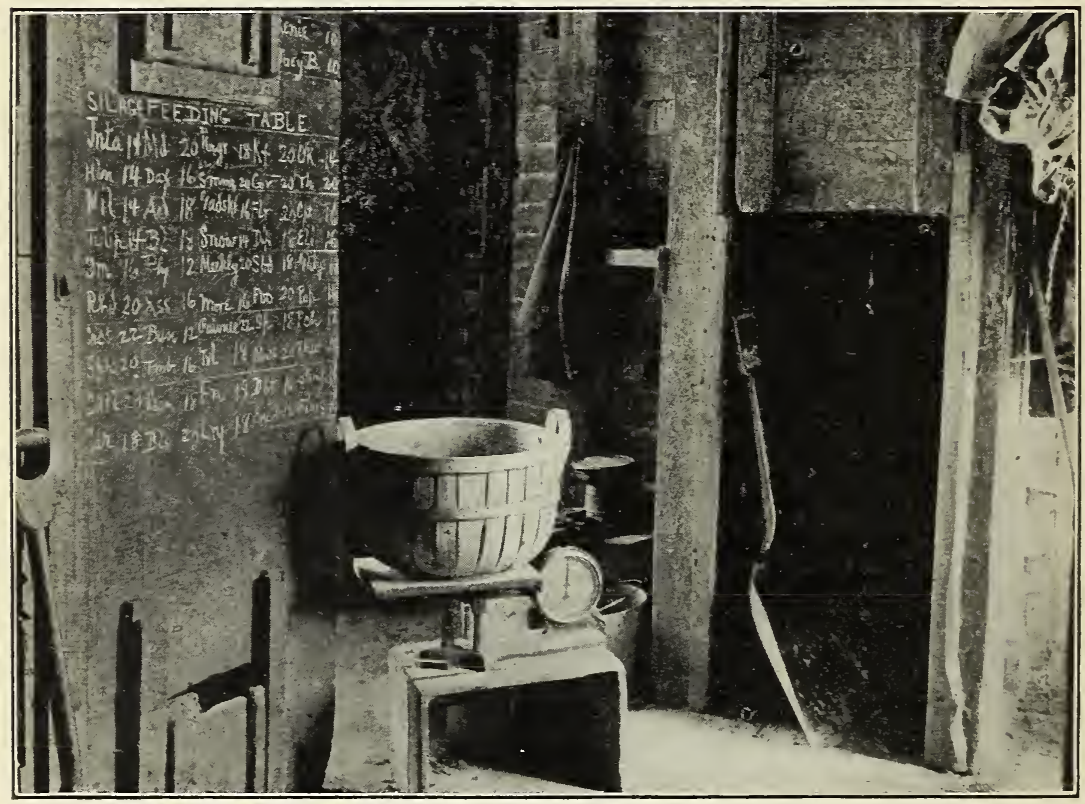

FIG. 1.-Outfit for weighing silage on Wisconsin farm. Silage, as well as the grain ration, is weighed out to each cow. The owner finds that a definite feeding system results in increased production.

year, and in 1912 the average quantity per cow was 1,300 pounds, or a little over 7 pounds per day for the period fed in the barn.

The dry roughage consisted of clover, alfalfa, mixed hay, corn stover, and straw for bedding. The quantity varied with the proportion of each kind of roughage used and its quality. The decrease in the quantity of concentrates and dry roughage per cow was partially offset by a gradual increase in the quantity of silage. (See Fig. 1.) The pasture period varied with the season. The increase in cost the last year is due to an increase in pasture value. In spite of variations in quantities the total feed cost was nearly constant throughout the four years. 
The average price per ton of the mixture of concentrates for each of the years was $\$ 26.56, \$ 24.26, \$ 24.40$, and $\$ 29.40$, respectively, the average for the four years being $\$ 26.16$. The average price per ton of all dry roughage ranged from $\$ 7.51$ to $\$ 11.48$, the average for the four years being $\$ 8.71$. The four-year average price of alfalfa was $\$ 12.75$, mixed and clover hay $\$ 8.50$, and corn stover $\$ 3.04$ per ton. Silage, including some green corn, was valued at from $\$ 3.13$ to $\$ 4$ per ton, the yearly average being $\$ 3.68$.

TABLE III.-Annual quantity of feed and its cost per cow on the Wisconsin farm.

\begin{tabular}{|c|c|c|c|c|c|c|c|c|c|}
\hline \multirow{2}{*}{ Year. } & \multicolumn{2}{|c|}{ Concentrates. } & \multicolumn{2}{|c|}{ Dry roughage. } & \multicolumn{2}{|c|}{ Silage. } & \multicolumn{2}{|c|}{ Pasture. } & \multirow{2}{*}{$\begin{array}{l}\text { Total } \\
\text { feed } \\
\text { cost. }\end{array}$} \\
\hline & Quantity. & Value. & Quantity. & Value. & Quäntity. & Value. & Days. & Value. & \\
\hline $\begin{array}{l}1909 \ldots \\
1910 \ldots \\
1911 \ldots \\
1912 . .\end{array}$ & $\begin{array}{r}\text { Pounds. } \\
1,920 \\
1,600 \\
1,588 \\
1,310\end{array}$ & $\begin{array}{r}\$ 25.52 \\
19.42 \\
19.78 \\
19.26\end{array}$ & $\begin{array}{r}\text { Pounds. } \\
2,005 \\
2,546 \\
1,780 \\
1,297\end{array}$ & $\begin{array}{r}\$ 8.53 \\
9.55 \\
7.70 \\
7.46\end{array}$ & $\begin{array}{r}\text { Pounds. } \\
6,754 \\
7,010 \\
7,160 \\
7,401\end{array}$ & $\begin{array}{r}\$ 10.59 \\
14.02 \\
14.32 \\
13.20\end{array}$ & $\begin{array}{l}184 \\
214 \\
184 \\
198\end{array}$ & $\begin{array}{r}\$ 6.02 \\
6.42 \\
6.10 \\
8.83\end{array}$ & $\begin{array}{r}\$ 50.66 \\
49.41 \\
47.90 \\
48.75\end{array}$ \\
\hline A verage, 4 years. & 1,605 & 21.00 & 1,907 & 8.31 & 7,081 & 13.03 & 195 & 6.84 & 49.18 \\
\hline
\end{tabular}

THE MICHIGAN FARM.

Table IV gives a summary of the quantity of feed consumed per cow and its costs for the Michigan farm herd for the years 1909 to 1912. Only the last three years are considered in obtaining an average to show the typical feeding methods practiced on this farm. The smaller quantities and value of feeds consumed per cow in 1909 are due to the fact that a number of heifers were fed in the herd the full year, although not giving milk except for a few weeks toward the end of the year. The larger quantity of concentrates and silage per cow on this farm for the year does not mean a larger daily ration, since the cows were stall-fed throughout the year. The use of the lot for pasture and exercise was charged to them on the basis of cost for interest, taxes, and fencing repairs. Expenses for feed and bedding are quite uniform for 1910 to 1912. Approximately 47 per cent of this feed cost is for concentrates, 26 per cent for dry roughage, 25 per cent for silage, and 2 per cent for pasture. The concentrates were fed in the form of mixtures, consisting principally of bran, dried beet pulp, cottonseed meal, gluten feed, and ground beans. Bran was usually purchased in carload lots. The average price per ton of the mixture of concentrates was $\$ 21.84, \$ 22.92, \$ 24.78$, and $\$ 23.52$, respectively, the four-year average being $\$ 23.36$. About one-third of the dry roughage consisted of alfalfa, and most of the remainder was timothy and clover hay, the average price per ton of each being $\$ 17.74$ and $\$ 12.61$, respectively. A small quantity of corn husks and straw valued at $\$ 5$ per ton was used. The average yearly price for all dry roughage was $\$ 14$ per ton, and silage was valued at $\$ 3$ per ton each year. 
TABLE IV.-Annual quantity of feed and its cost per cow on the Michigan farm.

\begin{tabular}{|c|c|c|c|c|c|c|c|c|c|}
\hline \multirow{2}{*}{ Year. } & \multicolumn{2}{|c|}{ Concentrates. } & \multicolumn{2}{|c|}{ Dry roughage. } & \multicolumn{2}{|c|}{ Silage. } & \multicolumn{2}{|c|}{ Pasture.1 } & \multirow{2}{*}{$\begin{array}{l}\text { Total. } \\
\text { feed } \\
\text { cost. }\end{array}$} \\
\hline & Quantity. & Value. & Quantity. & Value. & Quantity. & Value. & Days. & Value. & \\
\hline $\begin{array}{l}1909 \ldots \\
1910 \ldots \\
1911 \ldots \\
1912 \ldots\end{array}$ & $\begin{array}{r}\text { Pounds. } \\
2,220 \\
2,940 \\
2,854 \\
2,770\end{array}$ & $\begin{array}{r}\$ 24.24 \\
33.70 \\
35.38 \\
32.60\end{array}$ & $\begin{array}{r}\text { Pounds. } \\
2,900 \\
3,040 \\
2,606 \\
2,342\end{array}$ & $\begin{array}{r}\$ 10.85 \\
19.78 \\
17.08 \\
19.10\end{array}$ & $\begin{array}{r}\text { Pounds. } \\
9,880 \\
12,240 \\
11,5 i 2 \\
11,103\end{array}$ & $\begin{array}{r}\$ 14.81 \\
18.36 \\
17.38 \\
16.72\end{array}$ & & $\begin{array}{r}\$ 1.94 \\
1.24 \\
.95 \\
2.88\end{array}$ & $\begin{array}{r}\$ 51.84 \\
73.08 \\
70.79 \\
71.30\end{array}$ \\
\hline A rerage, 3 jears ${ }^{2}$. & 2,855 & 33.89 & 2,663 & 18.65 & 11,638 & 17.49 & & 1.69 & 271.72 \\
\hline
\end{tabular}

1 Charge for use of lot used throughout the year for exercise.

2 The year 1909 not included in average.

THE PENNSYLVANIA FARM.

Table $\mathrm{V}$ gives a summary of the quantity and cost of feeds consumed per cow by the Pennsylvania farm herd, 1910-1913.

Table V.-Annual quantity of feed and its cost per cow on the Pennsylvania farm.

\begin{tabular}{|c|c|c|c|c|c|c|c|c|c|}
\hline \multirow{2}{*}{ Year. } & \multicolumn{2}{|c|}{ Concentrates. } & \multicolumn{2}{|c|}{ Dry roughage. } & \multicolumn{2}{|c|}{ Silage. } & \multicolumn{2}{|c|}{ Pasture. } & \multirow{2}{*}{$\begin{array}{l}\text { Total. } \\
\text { feed } \\
\text { cost. }\end{array}$} \\
\hline & Quantity. & Value. & Quantity. & Value. & Quantity. & Value. & Days. & Value. & \\
\hline $\begin{array}{l}1910 \ldots \\
1911 \ldots \\
1912 \ldots \\
1913 \ldots\end{array}$ & $\begin{array}{r}\text { Pounds. } \\
1,399 \\
1,486 \\
1,332 \\
1,473\end{array}$ & $\begin{array}{r}\$ 17.06 \\
19.76 \\
16.71 \\
17.51\end{array}$ & $\begin{array}{r}\text { Pounds. } \\
2,020 \\
1,908 \\
2,455 \\
2,817\end{array}$ & $\begin{array}{r}\$ 10.23 \\
7.52 \\
12.77 \\
9.39\end{array}$ & $\begin{array}{r}\text { Pounds. } \\
7,537 \\
8,915 \\
8,032 \\
8,760\end{array}$ & $\begin{array}{r}\$ 14.42 \\
21.28 \\
19.47 \\
21.89\end{array}$ & $\begin{array}{l}154 \\
178 \\
193 \\
221\end{array}$ & $\begin{array}{r}\$ 3.55 \\
4.10 \\
4.44 \\
5.08\end{array}$ & $\begin{array}{r}\$ 45.26 \\
52.66 \\
53.39 \\
53.87\end{array}$ \\
\hline Average, 4 years. & 1,423 & 17.76 & 2,308 & 9.98 & 8,311 & 19.27 & 187 & 4.30 & 51.30 \\
\hline
\end{tabular}

In feeding concentrates, not as much difference was made in the quantity given to low yielding and high yielding cows as would hare been made had the production per cow been used as the basis of compounding the ration. The difference, however, amounted to as much as $\$ 13$ per year in the value of concentrates fed to individual cows. The mixture of concentrates, for the most part, consisted of sucrene and corn-and-cob meal. Some brewers' grains, gluten feeds, cottonseed meal, and dried beet pulp, were used. The dry roughage consisted of corn storer, alfalfa, and mixed hay, and wheat straw for bedding. The rariation in total quantity from year to year is due largely to the difference in the quantity of corn storer. Although the quantity of silage raries somewhat from year to year, the arerage is about four tons per cow per year. The pasture season was increased each year by making greater use of the aftermath on hay meadows. The arerage price per ton of concentrates for the four years was $\$ 24.38, \$ 26.60, \$ 25.10$, and $\$ 23.78$, respectirely, the arerage per year being $\$ 24.95$. The arerage price per ton of all dry roughage varied from $\$ 6.60$ to $\$ 10.40$, the average per year being $\$ 8.65$. The charge made for silage varied from $\$ 3.83$ to $\$ 5$ per ton, the average per year being $\$ 4.64$. 
NORTH CAROLINA FARM.

Table VI gives a summary of the quantities and cost of feed consumed per cow by the North Carolina farm herd, 1908-1914, inclusive. Owing to a marked change in the method of feeding in 1914, when the cows were stall-fed most of the year, the figures for this year were omitted in making a representative yearly average for the farm. The kinds of feed available on this farm, owing to its location, are distinctly different from those on the three northern farms. The basis of the concentrates used in the ration was cottonseed meal supplemented with dried beet pulp. Small quantities of gluten feed, bran, corn meal, and patent feeds were also used. The concentrates were mixed and apportioned to the cows on the basis of individual production, and the quantity fed per cow increased from year to year. A large portion of the dry roughage was cottonseed hulls, which were purchased locally at about $\$ 6$ per ton. Other roughage consisted of home-grown hay, made from peanut vines, soy beans, cowpeas, and mixed grasses and clover. Beginning in 1909 , the addition of silage to the ration resulted in a reduction of both concentrates and dry roughage. However, each succeeding year a larger quantity of concentrates was fed, while the dry roughage remained about constant, except for 1914, when the cows depended less on pasture.

TABLE VI.-Annual quantity of feed and its cost per cow on the North Carolina farm.

\begin{tabular}{|c|c|c|c|c|c|c|c|c|c|}
\hline \multirow{2}{*}{ Year. } & \multicolumn{2}{|c|}{ Concentrates. } & \multicolumn{2}{|c|}{ Dry roughage. } & \multicolumn{2}{|c|}{ Silage. } & \multirow{2}{*}{$\begin{array}{l}\text { Soiling } \\
\text { crops. }\end{array}$} & \multirow{2}{*}{$\begin{array}{c}\text { Pas- } \\
\text { ture } \\
\text { value. }\end{array}$} & \multirow{2}{*}{$\begin{array}{l}\text { Total } \\
\text { feed } \\
\text { cost. }\end{array}$} \\
\hline & Quantity. & Value. & Quantity. & Value. & Quantity. & Value. & & & \\
\hline $\begin{array}{l}1908 \ldots . \\
1909 \ldots \ldots \\
1910 \ldots \ldots \\
1911 \ldots . \\
1912 . \ldots \\
1913 . \ldots \\
1914 \ldots \ldots\end{array}$ & $\begin{array}{r}\text { Pounds. } \\
1,957 \\
1,627 \\
2,137 \\
2,616 \\
2,740 \\
2,843 \\
3,107\end{array}$ & $\begin{array}{r}\$ 28.06 \\
23.36 \\
32.37 \\
40.40 \\
36.12 \\
41.60 \\
45.04\end{array}$ & $\begin{array}{r}\text { Pounds. } \\
6,261 \\
4,566 \\
3,793 \\
3,771 \\
3,781 \\
3,613 \\
5,298\end{array}$ & \begin{tabular}{|r|}
$\$ 21.07$ \\
13.69 \\
14.33 \\
12.91 \\
9.78 \\
12.08 \\
16.57
\end{tabular} & $\begin{array}{r}\text { Pounds. } \\
5,268 \\
2,712 \\
6,800 \\
3,013 \\
5,407 \\
6,223\end{array}$ & $\begin{array}{r}\$ 13.18 \\
6.78 \\
17.00 \\
7.53 \\
13.53 \\
15.56\end{array}$ & \begin{tabular}{c} 
Value. \\
\hdashline$\$ 3.67$ \\
\hdashline 3.27 \\
\hdashline 6.95
\end{tabular} & $\begin{array}{r}\$ 4.05 \\
3.88 \\
4.41 \\
3.02 \\
3.50 \\
3.76 \\
1.36\end{array}$ & $\begin{array}{r}\$ 53.18 \\
54.11 \\
61.56 \\
73.33 \\
60.20 \\
70.97 \\
85.48\end{array}$ \\
\hline A verage, 6 years ${ }^{1}$. & 2,320 & 33.65 & 4,298 & 13.98 & 3,867 & 9.67 & 1.16 & 3.77 & 62.62 \\
\hline
\end{tabular}

11914 not included in average.

During three summers soiling crops were used to supplement silage. The increased total quantity of feed consumed each succeeding year is reflected in an upward trend in the total cost of feed per cow for the period. Variation in the price per ton of corn-andcob meal is reflected in the total cost of feed. From 1908 to 1914 the prices per ton paid for this meal, bought in large quantities, were, by years, $\$ 28.55, \$ 28.54, \$ 30.07, \$ 31.04, \$ 25, \$ 26.50, \$ 27$, and $\$ 22$, the average per year for the period being $\$ 28.13$. The price of beet pulp ranged from $\$ 29.30$ to $\$ 32$, with an average of $\$ 30.57$. The price per ton of the feeding mixture varied from $\$ 26.36$ to $\$ 30.89$, $68922^{\circ}-$ Bull. $501-17-2$ 
the arerage being $\$ 29.03$. The price per ton of corn stover ranged from $\$ 5$ to $\$ 6$. Hay ranged from $\$ 4$ to $\$ 10$ per ton, according to kind and quality. Silage was valued at about $\$ 5$ per ton. The average price of all dry roughages ranged from $\$ 5.17$ to $\$ 8.13$, with an average of $\$ 6.51$. Owing to the prices of feed materials in this section the average cost of feeding a cow on this farm is high.

These records show that a ration having as a basis cottonseed meal, even at southern prices, is more expensive than a ration with corn as a basis at prices prevailing on northern farms at the time of this investigation. The concentrates on this farm constitute 54 per cent of the total feed cost, which is from 7 to 20 per cent higher, proportionately, than on the three northern farms.

\section{LABOR.}

In the production of milk the cost of labor on these four farms is second in importance to feed. As shown in Table I, the labor is approximately one-fourth of the total cost of keeping a dairy cow, or about one-half the cost of feed. This labor includes the work of men and horses required to feed and care for cows, handle the milk, and market the products. Man labor is charged on the basis of the complete cost of hired labor on each farm; that is, the rate per hour is obtained by adding to the cash wages the value of board and other perquisites and dividing this total by the total number of hours of all hired labor. Horse labor is charged on the basis of cost, and the rate per hour is obtained by dividing the total cost of keeping the horses on the farm by the number of hours of horse work.

TABLE VII.-Number of hours of man and horse labor required per cow per year to produce milk and deliver it at the railroad station on each of the four farms.

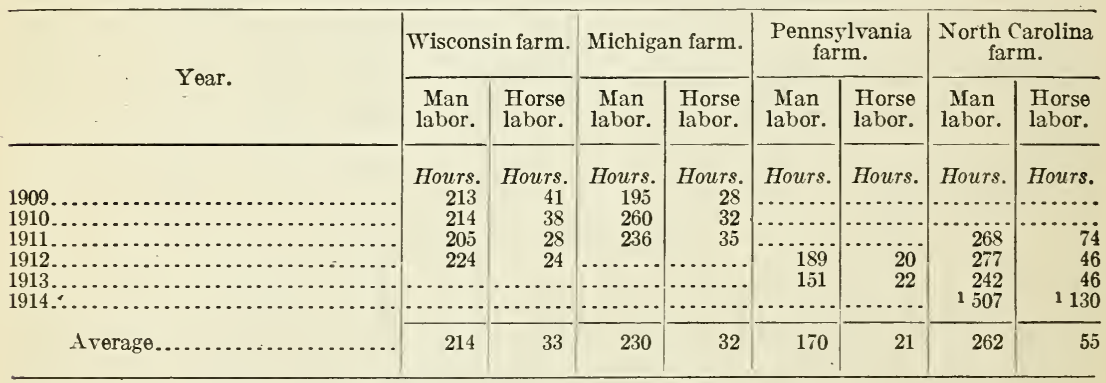

${ }^{1} 1914$ not included in average.

Table VII gives the hours of labor required per cow for each of the four farms. The highest labor requirement is on the North Carolina farm. This is due, in part, to the fact that the herd is the smallest and the distance to market greatest. The extra labor of bottling and retailing the milk in 1914 accounts for the greater labor requirement of the last year. Owing to this extra labor for retail marketing figures for this year are omitted in the farm average. 
The lowest labor requirement per cow is on the Pennsylvania farm, where the milk is handled quite efficiently and delivered at a near-by railroad station. The fact that the cows receive less individual attention and on the average produce less may have some influence in making the labor requirement lower. The use of a milking machine during 1913 made the man-labor requirement 38 hours per cow less than for 1912. The actual time of milking was reduced about one-half. The horse labor, mostly used in delivering milk, remained about the same each year. With the exception of the Pennsylvania farm, the average man-labor requirement per cow, exclusive of marketing, on each of the farms for all years is approximately 200 hours. This is equivalent to an average of 33 minutes per cow per day, 365 days in the year.

The hauling of milk to market is a daily operation on each of the farms. The hours of labor required per cow for this work varies with distance from market, size of the herd, and condition of the road. On the Pennsylvania farm it required 13.4 hours of man labor for this work as compared to 40.3 hours on the North Carolina farm, where less milk was hauled about four times as far. On the Wisconsin farm, 1 mile from the creamery, it averaged 16 hours per cow.

It is of interest to compare the man-labor requirement on the North Carolina farm in 1914 with other years. For nine months of this year the milk was retailed in the same city where it had previously been sold in bulk to a dealer. The actual hours of man labor required at the farm increased from an average of 222 hours per cow to 358 hours. This increase of 136 hours represents mainly the increased labor for extra handling and bottling the milk and caring for equipment put in use when the change was made to selling at retail. The time spent in marketing increased from 40 hours to 149 hours per cow. The horse-labor requirements increased in like proportion.

Table VIII gives the wage rates per hour for man and horse labor that were used in charging each herd for labor. The average rate per hour of man labor varied from 9 cents on the North Carolina farm, where the wages paid hired labor were low (about $\$ 20$ per month with board and lodging), to nearly 14 cents on the Wisconsin farm, where more efficient men were paid wages that averaged about $\$ 32$, with board and lodging.

TABLE VIII.-Cost per hour of man and of horse labor on the four farms.

\begin{tabular}{|c|c|c|c|c|c|c|c|c|}
\hline \multirow{2}{*}{ Year. } & \multicolumn{2}{|c|}{$\begin{array}{c}\text { Wisconsin } \\
\text { farm-rate per } \\
\text { hour. }\end{array}$} & \multicolumn{2}{|c|}{$\begin{array}{c}\text { Michigan } \\
\text { farm-rate per } \\
\text { hour. }\end{array}$} & \multicolumn{2}{|c|}{$\begin{array}{c}\text { Pennsylvania } \\
\text { farm-rate per } \\
\text { hour. }\end{array}$} & \multicolumn{2}{|c|}{$\begin{array}{c}\text { North Caroina } \\
\text { farm-rate per } \\
\text { hour. }\end{array}$} \\
\hline & Man. & horse. & Man. & Horse. & Man. & Horse. & Man. & Morse. \\
\hline $\begin{array}{l}1909 \ldots \\
1910 \ldots \\
1911 \ldots \\
1912 \ldots \\
1913 \ldots\end{array}$ & $\begin{array}{r}\text { Cents. } \\
13.3 \\
14.2 \\
13.6 \\
13.6\end{array}$ & $\begin{array}{r}\text { Cents. } \\
10.0 \\
8.9 \\
7.9 \\
7.9\end{array}$ & $\begin{array}{r}\text { Cents. } \\
12 \\
12 \\
12 \\
12\end{array}$ & $\begin{array}{r}\text { Cents. } \\
8 \\
8 \\
8 \\
8\end{array}$ & \begin{tabular}{r} 
Cents. \\
\hdashline$\ldots .$. \\
\\
12.9 \\
13.9
\end{tabular} & 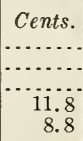 & \begin{tabular}{r} 
Cents. \\
\hdashline... \\
9.1 \\
9.0 \\
10.4
\end{tabular} & $\begin{array}{r}\text { Cents. } \\
7 . \\
7.0 \\
8.0 \\
8\end{array}$ \\
\hline
\end{tabular}




\section{USE OF BUILDINGS.}

The charge for the use of buildings is made up of interest, taxes, depreciation, and repairs on the buildings used for sheltering the cows and the necessary storage of cow feed. Interest was figured at the rate of 5 per cent on the average of the inventory value taken at the beginning and end of each year's record. The actual expense for repairs were taken from the financial and labor cost records. The farm taxes were apportioned to each enterprise on the farm on the basis of actual inventories of taxable properties. The charge for use of buildings was prorated to individual cows on the basis of the average number in the herd. It is expected that the charge per cow

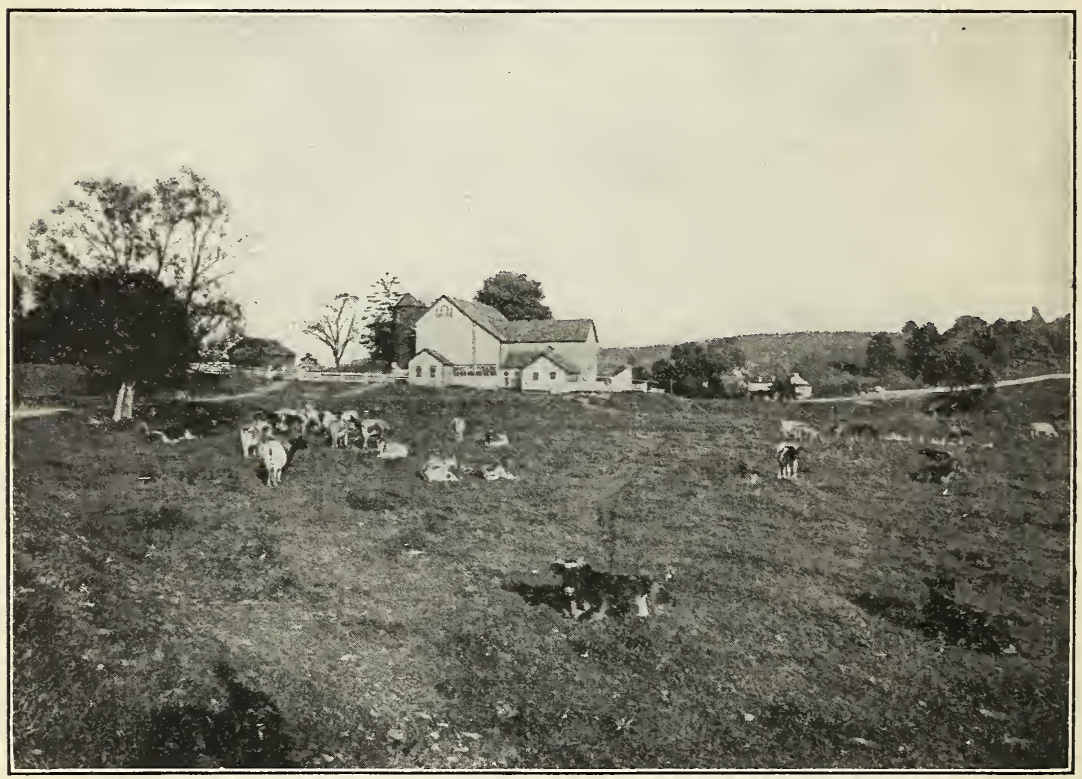

FIG. 2.-Barn on a dairy farm in southeastern Pennsylvania, in which the annual charge per cow for shelter is less than $\$ 5$ per year. The pasture, conveniently located, helps to keep down the labor charge.

for the use of buildings will vary on different farms, depending upon the housing efficiency, the value of the buildings used, and the size of the herd. It is not uncommon to find farms on which the dairy buildings are too high-priced to allow even a reasonably good cow to show a profit after paying her share of the annual cost for such buildings. The buildings on these four farms furnish adequate shelter for the cows at a moderate cost per cow. (See fig. 2.) The average yearly charge varies from 3.2 to 6.6 per cent of the total cost of keeping a cow. The average of the four farms is $\$ 4.74$ per cow.

\section{USE OF EQUIPMENT.}

The charge for the use of dairy equipment is relatively small. Although the rate of depreciation on dairy utensils is high, the 
amount of capital so invested per cow at any one time is comparatively small. Dairy equipment includes such items as separators, coolers, wagons, pails, cans, bottles, and other miscellaneous articles used in connection with the care of milk and the cows. The annual cost for these items includes depreciation, repairs, and interest on the average capital invested. The depreciation is the difference between the inventory value at the beginning of the year, plus the sum of all items purchased, and the inventory value at the end of the year. On these four farms this equipment charge, as shown in Table I, ranges from $\$ 1.28$ to $\$ 3.22$ per cow, which is from 1.3 to 2.5 per cent of the total cost of the cow per year.

USE OF BULL.

The net cost of keeping a bull is one of the expenses of producing milk. This cost includes feed, labor, interest, and depreciation. The last two items are in proportion to the value of the bull. Where heifers are raised to maintain the herd it has been proved to be poor economy to keep a scrub bull, however low the cost. The increased value at birth of the heifers sired by a bull of high quality will far more than offset the increased charge for use of the better bull. The size of the herd is also an important factor affecting the cost per cow. The charge for use of bull varies on each of the four farms, according to the number of cows and the value of the bull. This ranges from $\$ 1.47$ to $\$ 3.52$ per cow, the average being $\$ 2.44$. This is from 1.3 to 2.7 per cent of the total cost of keeping a cow. The highest charge is in the smallest herd, and the smallest charge is in the herd where there is the largest number of cows per bull.

\section{INTEREST.}

There is a certain amount of money invested in the cows of the dairy herd upon which the owner is entitled to receive interest. In these records interest is charged at the rate of 5 per cent on the average value of the cows for the year. This item ranges from 2 to 4.4 per cent of the total cost. The high interest charge on the North Carolina farm is due to the fact that several pure-bred Holstein heifers were purchased during the record period.

\section{DEPRECIATION.}

Some of the factors influencing depreciation charge are udder troubles, failure to breed, abortion, minor accidents, age, and death. Usually the loss from death is small compared with the shrinkage in value of cows sold at meat prices. The formula used in determining depreciation on each of the four herds is: First inventory value plus the value of cows entering by purchase or otherwise, minus the second inventory value plus the receipts from sales of cows, equals the amount of depreciation for any given period. The de- 
preciation per cow for each year was determined by dividing the total for the herd by the average number of cows.

On the Wisconsin farm there was no charge for depreciation, and only a small charge on the Michigan farm. The average value per cow increased from year to year in both of these herds during the record period. Grade cows were sold while still valuable for dairy purposes, and their places were filled by pure-bred heifers of home raising. The highest depreciation charge, $\$ 5.13$ per cow, is on the Pennsylvania farm, and, considering the average valuation per cow, this is a small charge. It is probable that, owing to the herd management, the charge for depreciation is lower on each of these farms than may be expected for a period of years on most dairy farms.

\section{MISCELLANEOUS ITEMS.}

There are a number of minor expenses in connection with the maintenance of every dairy herd, and for convenience these may be grouped under the heading of "miscellaneous items." These include veterinary services, fees to cow-testing association, registration fees, ice, and other dairy supplies. The total of these varies on each of the four farms, ranging from 66 cents to $\$ 2.93$ per cow, which is from one-half of 1 per cent to nearly 3 per cent of the total cost.

\section{OVERHEAD.}

There are a number of items of expense in the operation of a farm business that can not be charged directly to the individual enterprises. Important in this group are expenses for the general upkeep of the appearance of the farm, interest on money borrowed for general working capital, farm share of telephone rental, postage, and stationery. The importance of this item may be expected to vary greatly with the efficiency of management of the farm business. On these farms the overhead expenses were distributed to the productive enterprises on the basis of total cost for labor and materials. The dairy being the most important enterprise, it is made to carry its proportionate share. Overhead on these four farms varies from $\$ 4.84$ to $\$ 7.64$ per cow, and is 5 to 6 per cent of the total cost.

\section{CREDITS OTHER THAN MILK.}

There are certain credits apart from milk and milk products, such as value of manure, calf, and in some cases an appreciation in value of cows, which must be considered in determining the net cost of milk. While these credits affect the net cost of milk, they in no way change the proportion of any of the factors entering into the gross cost per cow; because, were the credits subtracted from each factor rather than from the total, the amount subtracted would be prorated to each item on the percentage basis. The total credits other 
than for dairy products on these farms range from $\$ 12.27$ to $\$ 20.33$ per cow and will offset from 25 to 30 per cent of all costs other than feed. (See fig. 3.)

TABLE IX.-Items of credit other than milk, their annual value per cow, and their relation to cost other than feed on the four farms.

\begin{tabular}{|c|c|c|c|c|}
\hline Item. & $\begin{array}{l}\text { Wisconsin } \\
\text { farm. }\end{array}$ & $\begin{array}{l}\text { Michigan } \\
\text { farm. }\end{array}$ & $\begin{array}{c}\text { Pennsyl- } \\
\text { vania } \\
\text { farm. }\end{array}$ & $\begin{array}{l}\text { North } \\
\text { Carolina } \\
\text { farm. }\end{array}$ \\
\hline 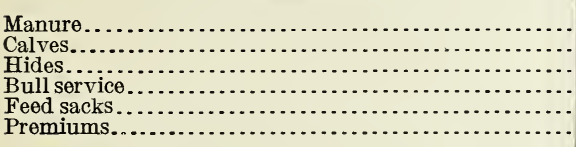 & $\begin{array}{r}\$ 10.47 \\
4.75 \\
.11 \\
.05 \\
.\end{array}$ & $\begin{array}{r}\$ 15.42 \\
4.52 \\
.08 \\
.08 \\
.30 \\
. . . \%\end{array}$ & $\mid \begin{array}{r}\$ 10.27 \\
1.16 \\
\cdots \cdots \\
\cdots\end{array}$ & $\begin{array}{r}\$ 10.64 \\
4.16 \\
.26 \\
.53 \\
1.22\end{array}$ \\
\hline Total... & 15.38 & 20.32 & 12.27 & 16.81 \\
\hline Per cent of costs other than feed. & 29.3 & 28.7 & 24.8 & 27.2 \\
\hline
\end{tabular}

Table IX gives these credits for the four farms, their amount per cow, and the relation which they bear to the costs other than feed. (See Table 1.)

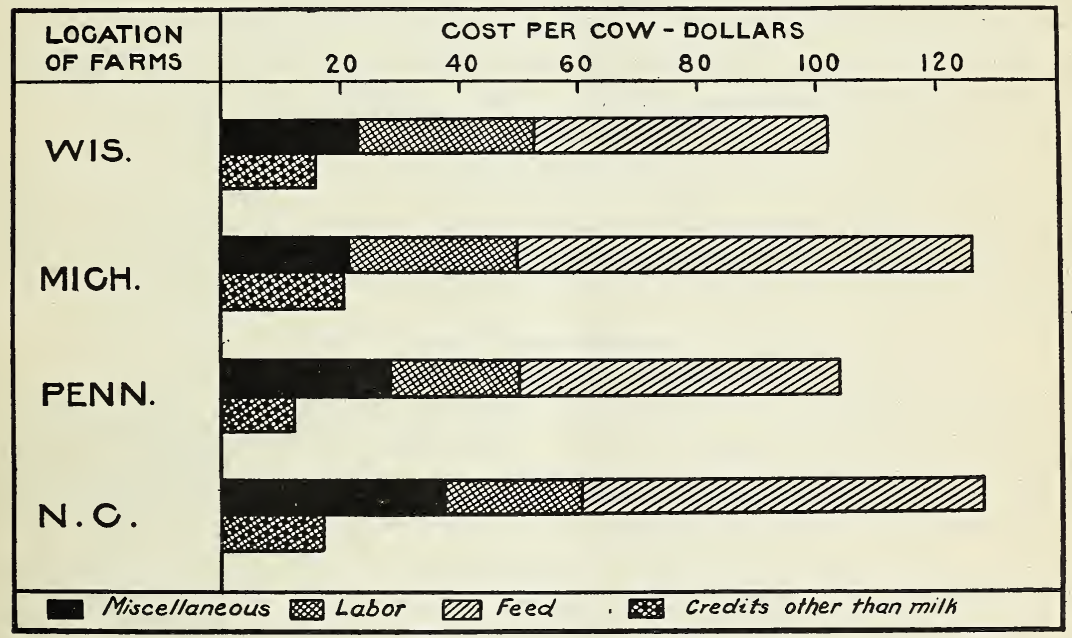

FIG. 3.-Relation between the credits other than milk and the total cost of keeping a cow on each of the four farms.

VALUE OF MANURE.

Manure is the most important credit. This was valued at $\$ 15$ per head per year for the Michigan farm and $\$ 10$ per head on each of the others. The value of manure produced by the herd bulls was credited to the cows, which accounts for the increase in the figures given in Table IX. The higher rate per cow on the Michigan farm is attributable to the fact that the cows are fed in the barn all the year, and thus more manure is recovered than on the other farms. 
These ralues are figured on the basis of a ton of manure being worth $\$ 1$ at the barn and on a production of approximately $1 \frac{1}{4}$ tons per cow per month during the period they are kept in the stable. From the data on three of these farms, showing the quantity of manure actually hauled to the fields, it is erident that the credit giren for manure is liberal. It is easy to orerestimate the actual credit value of manure per cow, and before deciding on a definite raluation for any herd it may be well to consider the care taken of the manure and the quantity that is actually returned to the land where crops can use it.

VALUE OF CALF.

The value of calres at birth depends upon their breeding and sex. Heifer calres from high-producing grade cows are usually ralued higher than males. In regions where the main product of the dairy is market milk the common practice is to raise but few of the heifer calres. All the bull calres and most of the heifer calres are disposed of shortly after birth. On the Pennsylrania farm the number of heifers selected for raising was relatively small as compared with the numbers sold or killed at birth, so that the credits for calf ralues in this herd is low, amounting to but $\$ 1.16$ per cow. Calf credits on the other three farms are $\$ 4.16, \$ 4.52$, and $\$ 4.74$ per cow.

MITOR CREDITS.

Certain minor credits are shown on these farms as receipts for sale of hides, fees for bull services, fair premiums, and rebates for feed sacks.

APPRECIATION CREDIT,

In some herds for certain years, or for a period of rears, there may be a credit for appreciation. This may be the result of careful management in building up a higher producing herd by using a purebred sire and the introduction of pure-bred cows. This method of management accounts for the appreciation of $\$ 6.37$ per cow on the Tisconsin farm. Adding this appreciation credit to the \$15.38, as giren in Table IX, the percentage of costs other than feed offset by credits on this farm is increased from 29.3 to 41.2 per cent. On the North Carolina farm there is an appreciation for one year, which is more than offset by the depreciation of other years, and the result is an arerage net depreciation of $\$ 3.52$ per cow, as shown in Table I.

The question of depreciation is discussed farther on (see p. 26.)

\section{QUANTITY OF MILK PRODUCED.}

Table $\mathrm{X}$ gires the arerage quantity of milk produced per cow on the four farms for each year production records are arailable. On three of these farms the yearly arerage is little orer 5,000 pounds 
per cow, while the Michigan farm shows a production above 6,000 pounds. In 1909 sereral heifers were added to the Michigan herd, and their yield, while not low for heifers, pulled down the average. Heifers also account in part for the lower yields on the Wisconsin farm for 1910, 1911, and 1912. Frequent indiridual butter-fat tests were made on all except the North Carolina farm. Of these, the two Jersey herds, Wisconsin and Michigan, have an arerage production of 256 and 281 pounds of butter fat, respectively, which gives an arerage test of 4.89 and 4.47 per cent, respectively.

According to the Thirteenth United States Census (1910) the arerage milk production per cow in the 10 leading dairy States is less than 4,200 pounds, and the State showing the highest production has an average of but 4,470 pounds. From this comparison it may be seen that the herds on each of these four farms are representative of good dairy herds.

-TABLE X.-Quantity of mill and butter fat produced per cow per year on each of the four farms.

\begin{tabular}{|c|c|c|c|c|c|c|c|c|c|c|}
\hline \multirow{2}{*}{ Year. } & \multicolumn{3}{|c|}{ Wisconsin farm. } & \multicolumn{3}{|c|}{ Michigan farm. } & \multicolumn{3}{|c|}{ Pennsylvania farm. } & \multirow{2}{*}{$\frac{\begin{array}{c}\text { North } \\
\text { Carolina } \\
\text { farm. }\end{array}}{\text { Milk. }}$} \\
\hline & Milk. & Butt & erfat. & Milk. & Butt & erfat. & Milk. & Butt & erfat. & \\
\hline $\begin{array}{l}1909 \ldots \\
1910 \ldots \\
1911 \ldots \\
1912 \ldots \\
1913 \ldots \\
1914 \ldots\end{array}$ & $\begin{array}{c}\text { Pounds. } \\
5,550 \\
5,245 \\
4,990 \\
5,130\end{array}$ & $\begin{array}{r}\text { Per ct. } \\
4.93 \\
4.90 \\
4.91 \\
4.82\end{array}$ & $\begin{array}{c}\text { Pounds. } \\
274 \\
257 \\
245 \\
247\end{array}$ & $\begin{array}{c}\text { Pounds. } \\
5,590 \\
6,721 \\
6,722 \\
6,102\end{array}$ & $\begin{array}{r}\text { Perct. } \\
4.44 \\
4.48 \\
4.45 \\
4.53\end{array}$ & $\begin{array}{r}\text { Pounds. } \\
247 \\
301 \\
299 \\
276\end{array}$ & $\begin{array}{r}\text { Pounds. } \\
\ldots 5,805 \\
5,483 \\
5,273 \\
4,832 \\
\ldots \ldots . . .\end{array}$ & $\begin{array}{r}\text { Perct. } \\
\cdots \\
4.0 \\
4.2 \\
4.1 \\
4.1\end{array}$ & $\begin{array}{r}\text { Pounds. } \\
\times . . . . . \\
232 \\
230 \\
216 \\
198\end{array}$ & $\begin{array}{r}\text { Pounds. } \\
3,988 \\
4,542 \\
4,983 \\
5,056 \\
5,240 \\
6,381\end{array}$ \\
\hline A verage $1 . .$. & 5,240 & 4. 89 & 256 & 6,284 & 4.48 & 281 & 5,348 & 4.1 & 207 & 5,032 \\
\hline A verage ${ }^{2} \ldots$ & 5,240 & 4.89 & 256 & 6,536 & 4.48 & 293 & 5,053 & 4.1 & 207 & 5,142 \\
\hline
\end{tabular}

1 Average of all years for which reports are given.

2 A verage years for which complete and comparable costs are available. These are the average production figures used in determining cost per unit in Table XI. The years included in this average are: Wisconsin farm, 1909-1912; Michigan farm, 1910-1912; Pennsylvania farm, 1912 and 1913; North Carolina farm, 1911-1913.

NET COST PER UNIT OF PRODUCT.

Table XI shows the net yearly cost that is chargeable to the production of milk and the cost per unit of 100 pounds of milk, per 40-quart can, and per quart. The cost per pound of butter fat, not deducting credits for skim milk and buttermilk, is also shown. The cost per 100 pounds of milk varies from $\$ 1.52$ to $\$ 2.16$, and the cost of other units of measure rary in like proportions. The pounds of milk are changed to quarts by dividing by 2.15. The gross feed cost on the Wisconsin farm is 1.59 cents, as compared. with 2.43 cents per quart of milk on the North Carolina farm.

The relative proportion of each item of cost in the production of 100 pounds of milk, which is equally applicable to any other unit used in measuring the product of the dairy, is illustrated by fig. 4 .

$68922^{\circ}-$ Bull. $501-17-3$ 
These charts are constructed on the basis of cost per cow after deducting, pro rata, the credit for ralue of manure, calf, etc.
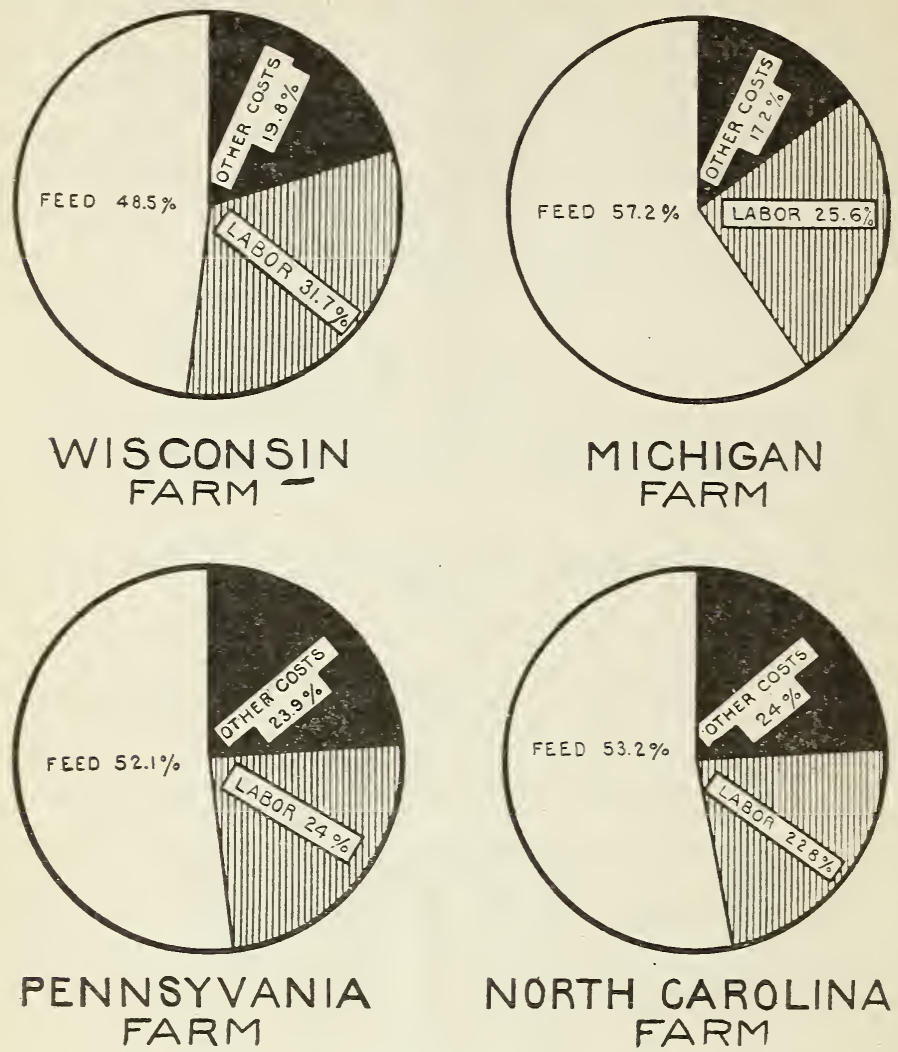

FIG. 4.-Relative importance of each item in the cost of producing 100 pounds of milk on each of the four farms.

The four dairy herds in question are well managed, and it is safe to say the production per cow for each is abore the arerage of the dairy herds of its community.

TABLE XI.- Yearly cost per cow, production per cow, and cost per unit of production on each of the four farms.

\begin{tabular}{|c|c|c|c|c|c|c|c|c|c|}
\hline \multirow{3}{*}{ Farm. } & \multicolumn{5}{|c|}{ Average per cow. } & \multicolumn{4}{|c|}{ Cost per unit of product. } \\
\hline & \multirow{2}{*}{$\begin{array}{l}\text { Total } \\
\text { cost. }\end{array}$} & \multirow{2}{*}{$\begin{array}{l}\text { Credit } \\
\text { other } \\
\text { than } \\
\text { milk. }\end{array}$} & \multirow{2}{*}{$\begin{array}{l}\text { Net } \\
\text { cost. }\end{array}$} & \multicolumn{2}{|c|}{ Yield. } & \multicolumn{3}{|c|}{ Milk. } & \multirow{2}{*}{$\begin{array}{c}\begin{array}{c}\text { Butter } \\
\text { fat. }\end{array} \\
\text { Pound. }\end{array}$} \\
\hline & & & & Milk. & $\begin{array}{c}\text { Butter } \\
\text { fat. }\end{array}$ & $\begin{array}{c}100 \\
\text { pounds. }\end{array}$ & $\begin{array}{l}40- \\
\text { quart } \\
\text { can. }\end{array}$ & Quart. & \\
\hline 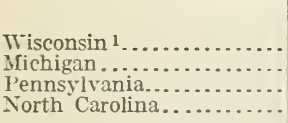 & $\begin{array}{r}\$ 101.61 \\
125.45 \\
103.12 \\
127.76\end{array}$ & $\begin{array}{l}\$ 21.75 \\
20.33 \\
12.27 \\
16.81\end{array}$ & $\begin{array}{r}\$ 79 . \$ 6 \\
105.12 \\
90.8 .5 \\
110.95\end{array}$ & $\begin{array}{r}\text { Pounds. } \\
5,240 \\
6,536 \\
5,053 \\
5,142\end{array}$ & $\begin{array}{c}\text { Pounds. } \\
256 \\
293 \\
207\end{array}$ & $\begin{array}{l}\$ 1.52 \\
1.61 \\
1.50 \\
2.16\end{array}$ & $\begin{array}{l}\$ 1.31 \\
1.35 \\
1.55 \\
1.56\end{array}$ & $\begin{array}{r}\text { Cents. } \\
3.23 \\
3.46 \\
3.87 \\
4.64\end{array}$ & $\begin{array}{r}\text { Cents. } \\
31.2 \\
35.9 \\
49.8\end{array}$ \\
\hline
\end{tabular}

1 The data compiled in this table are for the same years as those averaged in Table I. 
It is not within the scope of this bulletin to discuss the profits and losses in the production of milk on these four farms. Howerer, it may add interest to give the arerage receipts per cow from the sale of milk during the period covered by records, as shown in Table XII. Comparing the figures of Tables XI and XII, it will be seen that, on the arerage for the entire period, each of these farms made a profit from their dairies.

TABLE XII.-Average receipts per cow from sale of dairy products on each of the four farms.

\begin{tabular}{|c|c|c|c|c|}
\hline Year. & $\begin{array}{l}\text { Wisconsin } \\
\text { farm. }\end{array}$ & $\begin{array}{l}\text { Michigan } \\
\text { farm. }\end{array}$ & $\begin{array}{l}\text { Pennsyl- } \\
\text { rania } \\
\text { farm. }\end{array}$ & $\begin{array}{l}\text { North } \\
\text { Carolina } \\
\text { farm. }\end{array}$ \\
\hline $\begin{array}{l}1909 \ldots \ldots \\
1910 \ldots \ldots \\
1911 \ldots \\
1912 \ldots \\
1913 \ldots \ldots\end{array}$ & $\begin{array}{r}\$ 58.47 \\
82.72 \\
79.08 \\
80.92 \\
. . \%\end{array}$ & $\begin{array}{r}\$ 97.63 \\
123.72 \\
101.55 \\
120.92 \\
\ldots . .\end{array}$ & $\begin{array}{r}\$ 96.7 \\
113.45\end{array}$ & $\begin{array}{r}\$ 136.00 \\
130.76\end{array}$ \\
\hline Arerage... & 81.40 & 110.96 & 105.11 & 133.38 \\
\hline
\end{tabular}

\section{DATA FROM OTHER SOURCES.}

In connection with this same problem, other investigators hare published certain results. The publications from the New Hampshire, Massachusetts, and Connecticut ${ }^{1}$ (Storrs) agricultural experiment stations gire the cost per cow in sufficient detail, so that the items may be studied under the groups shown in Table I.

The relation of each item of cost to the total cost of keeping a cow as reported by the three New England experiment stations is giren in Table XIII.

TABLE XIII.-Relative importance of factors which make up the cost of producing milk as reported by three New England agricultural experiment stations. ${ }^{2}$

\begin{tabular}{|c|c|c|c|c|c|c|}
\hline \multirow{3}{*}{ Item. } & \multicolumn{6}{|c|}{ Cost per cow per year. } \\
\hline & \multicolumn{2}{|c|}{ Connecticut. ${ }^{3}$} & \multicolumn{2}{|c|}{ Massachusetts. ${ }^{3}$} & \multicolumn{2}{|c|}{$\begin{array}{l}\text { New Hamp- } \\
\text { shire. }^{3}\end{array}$} \\
\hline & $\begin{array}{l}\text { Actual } \\
\text { cost. }\end{array}$ & $\begin{array}{l}\text { Per } \\
\text { cent. }\end{array}$ & $\begin{array}{c}\text { Actual } \\
\text { cost. }\end{array}$ & $\begin{array}{l}\text { Per } \\
\text { cent. }\end{array}$ & $\begin{array}{c}\text { Actual } \\
\text { cost. }\end{array}$ & $\begin{array}{l}\text { Per } \\
\text { cent. }\end{array}$ \\
\hline Feed... & $\$ 85.02$ & 56.7 & $\$ 89.21$ & 54.9 & $\$ 73.03$ & 49.4 \\
\hline Labor: & 33.60 & 22.4 & 35.00 & 21.6 & 32.33 & 21.8 \\
\hline $\begin{array}{l}\text { Cows and dairy } \ldots \ldots \\
\text { Marketing } . . .6\end{array}$ & 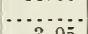 & $\ldots .$. & $\cdots \cdot \ldots$ & $\cdots \cdots$ & 7.18 & 4.9 \\
\hline $\begin{array}{l}\text { Use of buildings } \\
\text { Use of equipment } \ldots \ldots\end{array}$ & 3.95 & 2.6 & $\begin{array}{l}7.50 \\
1.15\end{array}$ & 4.6 & $\begin{array}{r}9.05 \\
.53\end{array}$ & 6.1 \\
\hline Use of bull....................................................... & 3.00 & 200 & 4.00 & 2.5 & 3.79 & 2.4 \\
\hline \multirow{2}{*}{ Interest } & 3.75 & 2.5 & 5.25 & 3.2 & 4.55 & 3.1 \\
\hline & 13.00 & 8.7 & 11.25 & 6.9 & 8.83 & 6.0 \\
\hline 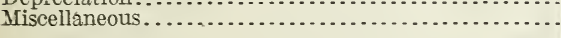 & 7.70 & 5.1 & 9.00 & 5.6 & 8.44 & 5.7 \\
\hline Total. . & 150.02 & 100.0 & 162.39 & 100.0 & 147.73 & 100.0 \\
\hline $\begin{array}{l}\text { Credits: } \\
\quad \text { Ianure and calf } \ldots \ldots \ldots \ldots \ldots \ldots \ldots \ldots \ldots \ldots \ldots\end{array}$ & \multicolumn{2}{|c|}{15.00} & \multicolumn{2}{|c|}{17.00} & \multicolumn{2}{|c|}{18.00} \\
\hline Arerage pounds milk per cow... & \multicolumn{2}{|c|}{6,378} & \multicolumn{2}{|c|}{6,036} & \multicolumn{2}{|c|}{6,463} \\
\hline
\end{tabular}

1 See $a, b$, and $c$ in "Literature Cited," p. 34 .

2 Other agricultural experiment stations have publications showing the cost of keeping a cow and the cost of producing milk, but the data are not presented in sufficient detail to be included in this table.

3 See $a, b$, and $c$, p. 34 . 
The data from Massachusetts and Connecticut are results from the experiment station.herds, while the data from New Hampshire are a compilation from all the herds of the Lyndeboro Cow Testing Association. These data differ in some respects from that procured from complete cost records. Howerer, considering the difference of conditions and methods under which the herds were handled, the results from all these sources closely coincide.

In each case the feed cost has been determined from actual records. Although many of the items other than feed were determined from estimates for the New England herds, they compare closely with the same items from actual records. By comparing Tables I and XIII, it will be seen that the total cost of keeping a cow, both on the two experiment station farms and in the cow-testing association, is somewhat higher than on the four farms discussed above. However, in terms of the proportion which feed, labor, and other costs bear to total cost, they check closely. In the feeding of a grain ration the entire year the Michigan herd is handled similarly to the Connecticut and Massachusetts experiment station herds, and the cost of feed in these three herds is $57.2,56.7$, and 55 per cent, respectively, of the total cost of keeping a cow.

The New Hampshire figures were compiled from farm herds where pasture was influential in reducing the feed cost. In this respect these herds are not unlike the Wisconsin, Pennsylvania, and North Carolina herds, and the feed is about one-half of the total cost.

The cost for labor, as shown by the New England records, is a little higher than on the four farms; however, the per cent of the total cost is a trifle lower. The cow-testing association record shows the total labor to be slightly more than one-fourth of the total cost, whereas at the experiment stations, where no marketing is included, the labor is less than one-fourth.

The individual items other than feed and labor show greater dirergencies, but considering them as a whole they compare fairly well. Some of the charges included in the individual items are not the same. For instance, "Orerhead" is entirely omitted from the New England records, and a part of equipment-cost charges are either omitted or were too closely linked with other items to be separated.

The item "Miscellaneous," as shown in Table XIII, takes care of a share of what might otherwise be called overhead. It also includes in each case a charge of about $\$ 5$ per cow for bedding. This item of expense may show up on many herds, but was so small on the four farms that it was included in the feed cost. Its consideration here tends to offset the items not given separately on the New England records. 


\section{DISCUSSION OF RESULTS.}

In taking up the consideration of the data from the four farms and of their practical application to the production of milk throughout the country, it is essential to note that milk and other dairy products are furnished by farms that may be divided into two general types. One type is the specialized dairy farm, where the source of income is primarily from dairy products. The whole farm organization is built around the dairy enterprise; labor is hired primarily to work on the herd; crops are grown for consumption by the herd; and the income of the owner is determined wholly by the efficiency with which the dairy is handled. Farms of this type are comparatively few in number and are found mostly in regions near large cities where there is a good demand for market milk. All four of these farms tend toward this specialized type. The Michigan farm is the most intensive. The second type, the general farm, is found everywhere throughout the country. The herd usually numbers from a few cows to 15 or 20 , but the keeping of cows is only a part of the general farm business. The farmer may sell some other kind of live stock, farm crops, or fruit. While the receipts from cows contribute to his income, his success or failure financially is but partially dependent upon the efficiency with which he cares for his cows. On the Pennsylvania and North Carolina farms considerable income is derived from the sale of other products.

\section{THE FEED PROBLEM.}

The results of this study indicate that on farms where cows depend on pasture, with little or no grain during the pasture season, the cost of feed is approximately one-half the total cost of keeping the cow. On farms where more intensive dairying is practiced, pasture is limited, and a grain ration is fed throughout the year, the feed is nearer 60 per cent of the cost. These facts further emphasize the point that, "with few exceptions, the feed bills are the real burden to the dairyman." ${ }_{1}$ Naturally, then, the producer of dairy products who would increase his profits by economizing in cost of production should first consider this largest item of cost. In many cases economy may result from an actual reduction of feed cost per cow, whereas, in other cases it may be necessary to increase the feed bills to insure the greatest profits. The quantity of feed supplied each cow should not be below the quantity she requires for the most efficient production. The real economic problem is to supply a palatable ration which contains the essential constituents in sufficient quantity at the lowest cost. (See fig. 5.) The fundamental principles of compounding a ration on the basis of nutrition have been determined by extensive experimental studies. 
The question of providing feed is different on each of the two general types of farms that maintain dairy cows. Just how near the specialized dairyman should come to growing all the feed required by his dairy herd is a question of individual business management. ${ }^{1}$ One man may find it most profitable to grow all the feed required, while another may increase his profits by supplementing the income from cows with crop sales and purchase a part of the feed. In a few localities in the United States crops may be selected that will not only yield a product for which there is ready sale at good prices, but also leave on the farm much feedable material. Sweet corn is an example of this type.

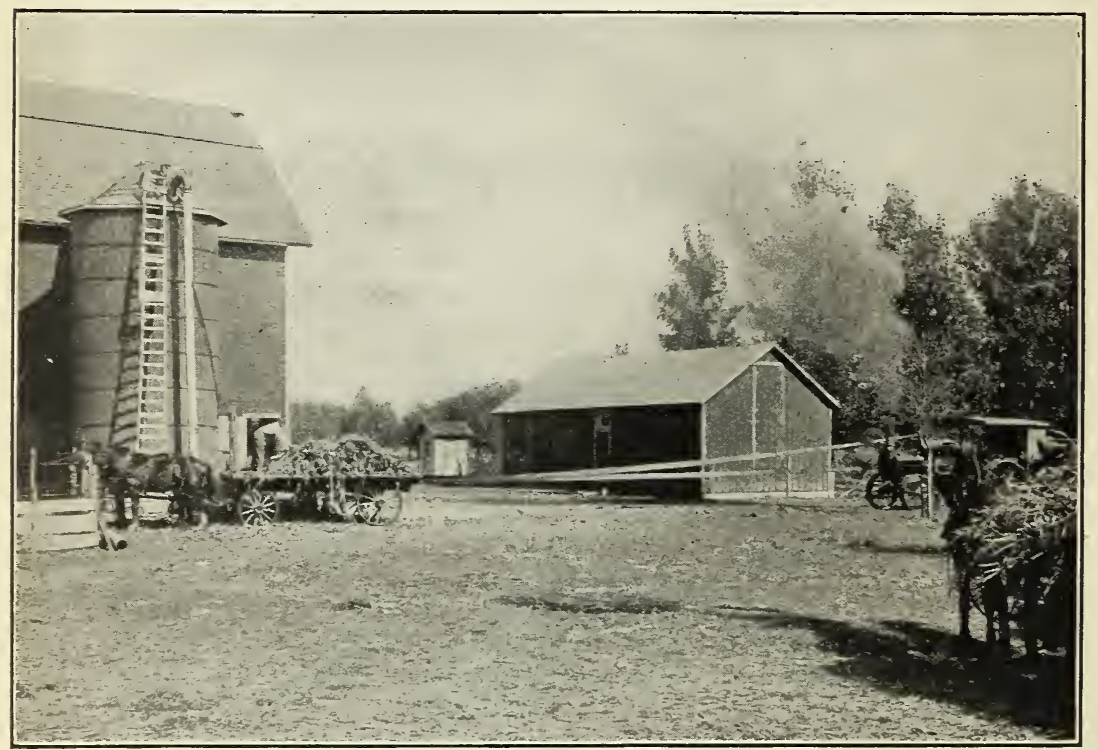

FIG. 5.-A silo is usually a profitable investment in connection with the feeding of dairy cows.

As a matter of fact, there was a wide variation on the four farms studied as to the practice of growing or buying the feed. On the Wisconsin farm concentrates were purchased in addition to feeding all the crops raised. The practice on the Michigan farm was similar in this respect to the Wisconsin farm, except that more feed was purchased, owing to the absence of sufficient pasture. On the other hand, the practice on the Pennsylvania farm was to sell wheat and timothy and to buy some concentrates. No roughage was sold from the North Carolina farm, where cotton and tobacco were important cash crops. The dairy cow ration was completed with purchased feeds. 
Where this practice of supplementing the dairy business with the production of cash crops is feasible, it is profitable for the dairyman to sell some crops and purchase concentrates. If, by the growing of a cash crop, it is possible from the net receipts of one acre to buy a quantity of concentrates equivalent to that which could be raised on $1 \frac{1}{2}$ or 2 acres, it would be folly to grow the concentrates. In other words, this class of feed should not be grown when it is possible to raise some other crop at a greater profit without seriously affecting the labor required on the farm.

The majority of the cows in the United States are found on the general or diversified farms. The herds on these farms are smaller than on the specialized dairy farm, but there are so many farms of this class that they produce the greater part of our dairy products, aside from market milk. Owing to the meagerness of the receipts per cow on many farms of this type, it is safe to assume that the complete cost of the product is often more than the actual cash receipts. Nerertheless, cows are kept on these farms, and have been kept for years. This would not be true if, on the average, their owners did not feel that their farms produced greater incomes with these cows than they could without them.

The principal reason that this class of farmers can continue to produce dairy products at an apparent loss, as shown by cost accounts, is that in connection with the profitable production and marketing of crops the cows consume by-products and low-grade materials, and also use land as pasture that otherwise would be wasted. Moreover, the manure recovered is beneficial in further crop production. The quantity of such feedable materials that otherwise might largely be wasted if not fed to live stock, is in great measure determined by the location of the farm in reference to markets. That is, what may be a by-product on a farm several miles from a railroad station or a city market may be a readily salable product on a farm close to market. Different cropping systems yield different quantities of these feedable materials. For example, a cropping system of potatoes, beans, wheat, and hay will yield less feedable by-products than corn, oats, wheat, and hay. Regardless of the quantity of these materials produced on diversified farms, the fact is that unless such materials are consumed and made into manure by live stock such would, in many cases, be a total waste. In practice, therefore, it is not a question of charging this feed on such farms at $\$ 3$, or $\$ 5$ or $\$ 7$ per ton, as must of course be done in cost accounting, but of utilizing otherwise valueless material in such a way that it will return something. The problem of these farmers is to make use of this roughage on the farm and to convert it into a product which has a ready market. These farmers have found that one of the best ways of doing this is by feeding it to dairy cows. 
The fact must not be overlooked that while for clearness in discussion dairy farms have been divided into the two general types, in actual conditions there are farms where dairying is found in every degree of intensity. As the farm becomes more specialized in character the feeding practice must be changed to conform with the individual conditions. Each farmer or dairyman must formulate his own ration, but in so doing it is necessary that he first learn what his feeding problem really is, and having done this, decide upon a feeding practice which will produce milk so that the dairy will contribute to the maximum farm profit.

\section{THE LABOR PROBLEM.}

The data presented above show that the labor item is second to feed in importance, and is approximately one-fourth of the total expense of keeping a cow. With the increased demands for cleaner dairy products it is reasonable to expect that in many cases more work will be necessary, both in caring for the cows and for the milk. This may also require more efficient labor on many farms and perhaps higher wages. In attempting to reduce the cost for labor it must be remembered that a cow responds to good treatment, and the efficiency of labor has a close relationship to the profitableness of the dairy business. This point is emphasized by the Minnesota Experiment Station ${ }^{1}$ in the following statement: "We know of many instances where the best of the dairy cows were kept and where good methods of feeding were practiced; and still results fell far short of what might reasonably be expected, simply because the animals did not receive the kindly treatment which is so essential to a cow giving much milk for a long period."

On specialized dairy farms where hand milking is practiced a number of laborers are hired primarily for work in the dairy. The dairy enterprise seldom provides work to keep the men profitably employed throughout the day, largely because more men are required to milk than are needed to do the other dairy work. It may be expected that the use of milking machines on these farms will change this labor requirement to some extent. Nevertheless, the same general principle holds good, that he who would economize on this expense for labor must provide other work during that part of the day when labor is not needed in the dairy. For this reason the growing of some field crops is always advisable. On each of the four farms from which data have been presented all labor used on the farms has been charged to the various enterprises at a uniform rate per hour Inasmuch as this labor was primarily employed for the dairy, it might seem logical to charge the portion thus used at a higher rate and to charge the labor used in the production of crops and on other farm work at a lower rate. It the same time, labor on the more general 
farm is hired primarily for the production of crops, and the use of this labor in the care of live stock supplements the crop labor, making it seem equally logical to charge crops at a high rate and the live stock at a low rate per hour. But no distinction of this kind has been made in this bulletin.

The cost of caring for the dairy cow on the more general farm is low. Extra workmen are seldom hired for this purpose. During the crop-growing season the cows are cared for in addition to the regular day's work in the field. Quite often the women and children do the milking, especially at times when crop work is heavy and the men are required to work late. Again, during the winter months there is little or no productive field work, and the dairy cows furnish

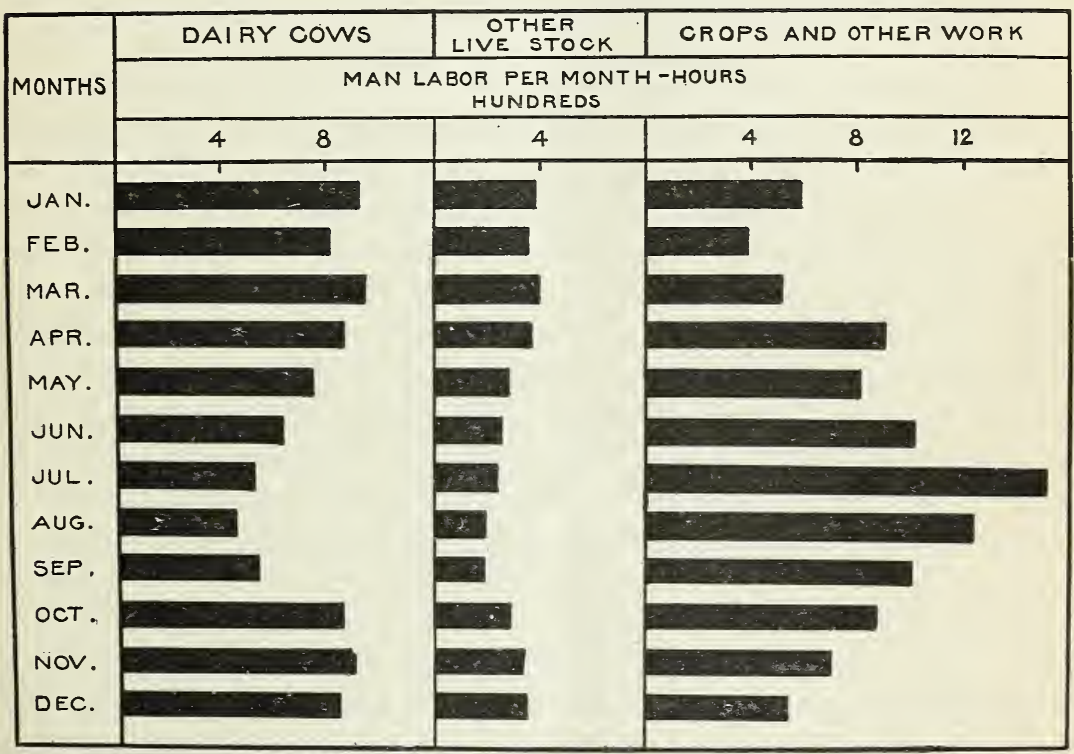

FIG. 6.-Distribution of man labor by months on the dairy enterprise as compared with the hours used by other live stock and that available for growing crops and other work on the Wisconsin farm, 1911.

employment for labor that would otherwise be idle. As a result of these conditions the actual cash outlay for labor is frequently no greater with a few cows on the farm than it would be without them. On these general farms, the same principle which is true for the feed is also true for labor; that is, it is not a question of getting 15 or 20 cents per hour for this labor, but of getting something, and in so doing increase the income of the farm business.

Figure 6 is a chart showing for the Wisconsin farm in 1911 the distribution of man labor by months on the dairy enterprise, as compared with the hours devoted to the care of other live stock and those devoted to growing crops and to other necessary work. This shows that the most labor on the dairy comes during the period from October to April. The system of winter dairying practiced on this farm 
provides for the maximum amount of labor arailable for other purposes during the period when most labor can be used in the production of crops. This also illustrates the fact that crop-production work does not provide full employment for labor throughout the year. On general farms the keeping of a certain number of cows can be made to supplement the crop labor and thus provide profitable employment all the year.

It is far better to fill in this winter time thus, even though the wages returned are low, than not to utilize it at all and receire nothing. This is another reason why cows are maintained on general farms where cost records, charging labor at full rates, show the returns to be less than the cost. Within certain limits, they may add to the profits of the farm business eren at an apparent loss.

\section{THE PROBLEM OF DEPRECIATION.}

Depreciation is a matter of little importance to the owner of a herd of poor cows. A poor dairy cow is ordinarily worth almost as much for beef as for dairy purposes and sometimes more. However, this item is of serious importance to the owner of high-priced dairy cows, for his worn-out cows are worth no more for beef than scrubs, and perhaps not so much. It is a known fact that annual depreciation increases with an increase in the value of the cow as a milk producer. The amount of depreciation may vary greatly from year to year on the same herd and with different methods of management. On the four farms studied it is comparatively low, whereas the literature now published indicates that on the average a much larger charge may be expected than was found on these farms. The Massachusetts Agricultural Experiment Station ${ }^{1}$ estimates that with cows having an average value of $\$ 75$ the annual depreciation per cow will amount to $\$ 11.25$. The Connecticut (Storrs) Agricultural Experiment Station ${ }^{1}$ found that the cost of maintaining the standard of the herd for a period of five years was $\$ 13.26$ per cow per year. The records of a cow-testing association in New Hampshire ${ }^{1}$ show the average life of a cow to be a little over four years. Calculations made from the dairy herd records published by the Nebraska Agricultural Experiment Station ${ }^{1}$ indicate that in herds where the poor cows are carefully culled out on the basis of production records practically one-third are discarded each year, thus making the average life in the herd not far from three years. ${ }^{2}$

\footnotetext{
1 See $b, c, a$, and $f$, p. 34 .

2 From the records published by the Nebraska Agricultural Experiment Station, Bulletin 139, it was found that during the period of 14 years 310 yearly records were procured from 110 different cows, which is an average of 2.82 years per cow. From the 71 cows which entered the herd and were later sold 198 yearly records were obtained. This is equivalent to an average productive life in the herd of 2.79 years. Of these 71 cows only 16 were kept five years or more, of which nine were retained five years, four six years, one seven years, one nine years, and one 12 years. From the 38 cows in the herd at the close of the period 110 yearly records were procured, which is an average of 2.90 years per cow. Of these 38 cows 12 had completed but one year, while 11 had been in the herd four years or more.
} 
In the recently-published results of a farm-management survey ${ }^{1}$ it is shown that on 378 farms in Chester County, Pa., operated by owners, the length of time the average cow remains in these herds is 4.34 years. The yearly charge for depreciation on these farms is very nearly $\$ 6.70$ per cow. For 300 farms in Lenawee County, Mich., the average cow remains in the herds 4.52 years, and the yearly charge for depreciation is very nearly $\$ 2.14 .^{2}$

With cows of good quality the amount of depreciation may be kept low by judicious selling. The heifers which are culled out can usually be sold without serious loss. The cows not discarded the first year usually increase in value up to a certain age and then decrease in value rapidly. Some dairymen keep their depreciation item to a minimum by placing the cow on the market for dairy purposes just before this decrease comes. However, this is a profitable practice only from the standpoint of the seller, for it must be remembered that the buyer must always stand the depreciation which the seller has evaded.

BUILDINGS, EQUIPMENT, ETC.

In erecting buildings for the dairy herd profit often depends on discretion. It is not unusual to find places where, if the cows paid interest on the money invested in dairy buildings, it would be impossible for them to pay for anything else. From an economic standpoint an investment in buildings beyond that required to provide adequately for comfort, convenience, and sanitation is a personal matter with the owner. While cows kept in palacelike buildings are perhaps more fortunate, it is doubtful whether they are

1 See $g$, p. 34 .

2 U. S. Department of Agriculture, Bull. 341, pp. 93-95. In this publication the rate of depreciation on dairy cows does not represent the annual rate at which an animal deteriorates after it passes its prime, for as the calculation is made the depreciation of such animals is in part cancelied by the increase in value of animals before they reach their prime. The method of calculation is the same as outlined on p. 13 of this bulletin, with proper adjustment being made for the increase or decrease of the selling price of cows during the year. But the rate obtained does represent approximately the average charge which must be made for depreciation in determining the cost of maintaining the dairy herd.

For 378 farms in the Chester County, Pa., area the average annual loss on dairy cows from depreciation in value was 11.82 per cent of the average of the inventory values for the beginning and the end of the $y$ ear. A similar calculation for 300 farms in Lenawee County, Mich., showed a corresponding rate of 4.07 per cent. The authors analyze these figures thus:

"In making these calculations it is assumed that it costs as much on the average to raise a dairy cow as the average price at which cows are purchased in the respective localities. This may be in error, but even if the cost be considerably less, the results would not vary greatly from those given, because of the relatively small proportion of cows raised, especially in the Pennsylvania area.

"The marked difference in the rate of depreciation of dairy cows in the two areas is due mainly to the difference in the prices at which cows are bought and sold in the two localities. In the Michigan locality the dairy farmers pay on the average $\$ 48.48$ for cows and sell their discards for $\$ 42$, a difference of only $\$ 6.48$, whereas the dairy farmers in the Pennsylvania locality pay an average price of $\$ 63.84$ and sell for $\$ 37.36$, a difference of $\$ 26.48$. Thus the Pennsylvania farmer loses $\$ 20$ more per cow bought and sold than does the Michigan farmer. This accounts for the much larger annual charge for depreciation on the Pennsylvania farms.

"In the Chester County area the farmers on the average raise 37 per cent of their cows and buy the remainder. In the Michigan locality they raise 57 per cent. The proportion of the average herd discarded yearly is 23 per cent in Pennsylvania and 21.6 per cent in Michigan. The average length of time the average cow remains in these herds is therefore 4.34 years $(=100 / 23)$ in Pennsylvania area and 4.52 years in Michigan area. The yearly percentage of deaths in the herds was 1.69 for Pennsylvania and 1.31 for Michigan." 
more productive than those housed in adequate quarters for which they are able to pay a reasonable rental charge. On the other hand, it is not uncommon to find cows so poorly housed that it is not possible for them to make a profitable yield. The location of the farm with reference to markets, the degree of cleanliness desired, as weil as the size and economic productivity of the herd, are factors to be considered in relation to an economic investment in buildings. Buildings which would be desirable and economical on a dairy farm near the city, where certified milk finds a ready market, would hardly be adapted to the use of a herd of the same size where the only market is a local cheese factory or creamery buying on the butter-fat basis. Neither would a herd having an average production per cow of 4,000 pounds of milk justify the same investment in buildings and equipment as one having an average of more than 6,000 pounds per cow.

The investment per cow in dairy buildings on the four farms discussed in previous pages is moderate, being $\$ 84$ on the Wisconsin farm, $\$ 50$ on the Michigan, $\$ 83$ on the Pennsylvania, and $\$ 80$ on the North Carolina farm. A larger herd is one reason for the lower investment per cow on the Michigan farm. Other things being equal, the larger the herd that can be accommodated with a given investment the lower the amount per cow.

The question of an economic investment in equipment and supplies is closely related to that of buildings, and the same general principles hold true in both cases. Expensive milk coolers and ice supplies, which may be absolutely necessary in the production of high-grade milk for a special market, might be both unnecessary and extravagant in the production of cream to be sold on the butter-fat basis. In other words, expenses for buildings, equipment, and supplies should never be so high as to make it difficult or impossible to realize a reasonable dividend on the capital invested in the herd.

The other items in the total cost of milk, including interest, expense for use of bull, miscellaneous items, and overhead, depend quite largely upon the efficiency of the management of the dairy herd and farm business. The charge of interest on money invested in cows is in direct proportion to the value of the cows.

The charge per cow for use of bull is largely in proportion to the value of the bull and the number of cows in the herd. In attempting to raise the general productivity of the herd through the selection and raising of heifers from the best cows, the influence of the quality of the bull in the herd is felt for years, and, within reasonable limits, any additional cost because of his quality will be far more than offset by the increased value of the heifer calves. Furthermore, there is a good market for calves of good breeding, and those not needed in the herd can be sold for much better prices than those sired by a scrub bull. 
The amount of the charges for miscellaneous items and overhead varies with the size, type of the business, and efficiency of the management:

In view of the fact that the assumption frequently has been made that the value of manure and calf will offset the costs other than feed, it is of interest to note the relation of these credits to the total cost of keeping a cow on the four farms. This relationship is shown in figure 3, page 15, data for which are taken from Tables I and IX. On these farms the credits for these items do not equal the cost items other than feed and labor combined and range from 25 to 29 per cent of items other than feed.

\section{RELATION OF INDIVIDUAL COW TO COST OF PRODUCTION.}

In the previous paragraphs the discussion of the data has related to the dairy herd as a unit. By referring to Tables XI and XII, it may be seen that each of the four farms shows a net profit per cow on this basis. The data from each of these farms were also obtained in sufficient detail to permit a study of the individual cows in relation to profitableness of production. Table XIV shows the relation of milk production and the cost per cow to the cost per 100 pounds of milk, based on data from 443 complete yearly records on four farms. The records were divided into production groups on the basis of even thousands of pounds per cow, beginning with those producing 3,000 pounds and less and ending with those having a production of over 8,000 pounds. The average production of 16 cows in the first group was 2,349 pounds, costing $\$ 83.90$, of which $\$ 43.93$ was for feed. The average production of 111 cows in the 5,001 to 6,000 -pound group was 5,450 pounds, costing $\$ 114.42$, of which $\$ 59.91$ was for feed. The average production of 36 cows in the 8,000 group and over was 9,049 pounds, costing $\$ 153.65$, of which $\$ 80.45$ was for feed.

TABLE XIV.-Relation of milk production and the cost per cow to the cost per 100 pounds of milk, based on data from 443 complete yearly records on four farms. ${ }^{1}$

\begin{tabular}{|c|c|c|c|c|c|c|c|}
\hline \multirow{2}{*}{ Basis of classification. } & \multirow{2}{*}{$\begin{array}{l}\text { Number } \\
\text { of cows. }\end{array}$} & \multirow{2}{*}{$\begin{array}{l}\text { Produc- } \\
\text { tion. }\end{array}$} & \multicolumn{3}{|c|}{$\begin{array}{c}\text { Arerage per cow per } \\
\text { year. }\end{array}$} & \multicolumn{2}{|c|}{$\begin{array}{l}\text { A rerage per } 100 \\
\text { pounds of milk. }\end{array}$} \\
\hline & & & $\begin{array}{l}\text { Feed } \\
\text { cost. }\end{array}$ & $\begin{array}{l}\text { Other } \\
\text { cost. }\end{array}$ & $\begin{array}{l}\text { Total } \\
\text { cost. }\end{array}$ & $\begin{array}{l}\text { Feed } \\
\text { cost. }\end{array}$ & $\begin{array}{l}\text { Total } \\
\text { cost. }\end{array}$ \\
\hline 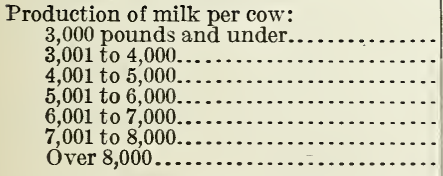 & $\begin{array}{r}16 \\
33 \\
78 \\
111 \\
109 \\
60 \\
36\end{array}$ & $\begin{array}{l}\text { Pounds. } \\
2,349 \\
3,648 \\
4,596.1 \\
5,450 \\
6,445 \\
7,513.5 \\
9,049\end{array}$ & $\begin{array}{r}\$ 43.93 \\
49.47 \\
55.00 \\
59.91 \\
62.85 \\
70.38 \\
80.45\end{array}$ & $\begin{array}{r}\$ 39.97 \\
45.01 \\
50.04 \\
54.51 \\
57.18 \\
64.04 \\
73.20\end{array}$ & $\begin{array}{r}\$ 83.90 \\
94.48 \\
105.04 \\
114.42 \\
120.03 \\
134.42 \\
153.65\end{array}$ & $\begin{array}{r}\$ 1.87 \\
1.36 \\
1.20 \\
1.10 \\
.93 \\
.94 \\
.89\end{array}$ & $\begin{array}{r}\$ 3.57 \\
2.59 \\
2.29 \\
2.10 \\
1.86 \\
1.79 \\
1.70\end{array}$ \\
\hline
\end{tabular}

1 The cost for individual cows on each farm was determined as follows: The item of feed was obtained from individual records; the items of labor, use of buildings, use of equipment, use of bull, and miscellaneous items for each year were divided pro rata on the basis of numbers; the items of interest and depreciation were obtained for individuals from inventory valuations; the item of overhead expenses was distributed on the basis of total cost for labor and materials the same as explained on p. 14 . 
The data in table XIV show the relation between the cost of keeping cows of varying milk yield and the cost of the milk. The same data are also shown in graphic form in figure 7 . It will be noticed that as milk yield increases there is also an increase in the feed cost and in other cost items, but not in the same proportion. Cows yielding less than 3,000 pounds produced milk at a cost of $\$ 3.57$ per hundred. Those yielding 5,001 to 6,000 pounds produced it at $\$ 2.10$ per hundred. Those yielding over 8,000 pounds produced it at $\$ 1.70$ per hundred. It is apparent, in so far as conclusions can be drawn from the records of these four herds, that the cost of producing milk from low-yielding cows is very high and that this cost gradually decreases with better cows. This decrease in cost is much greater

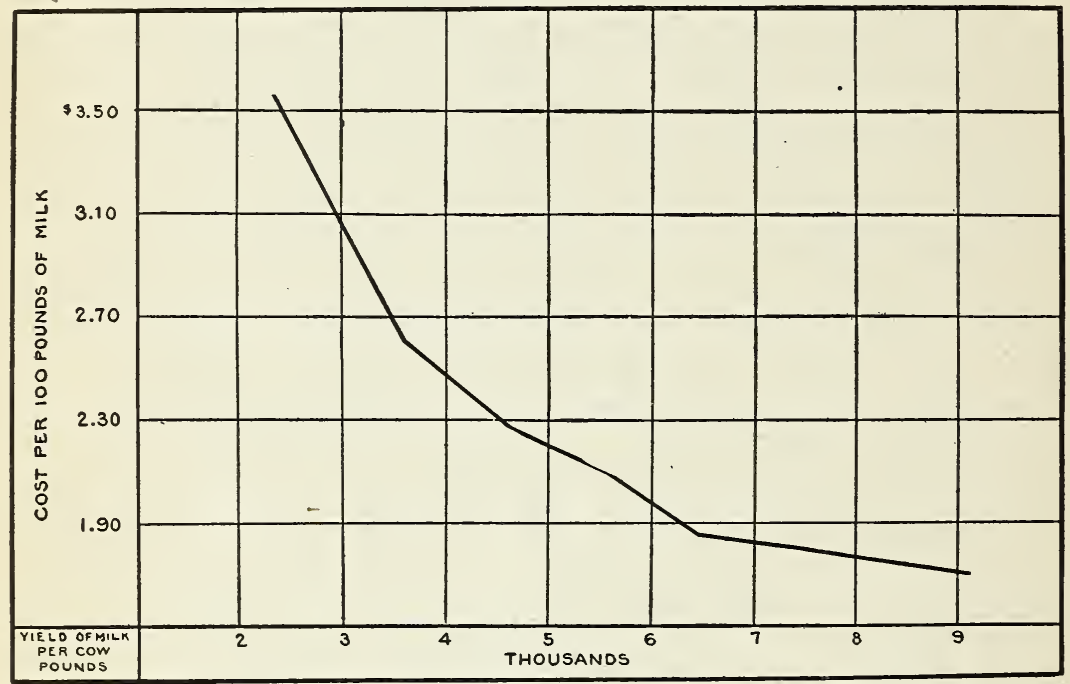

FIG. 7.-Relation between annual yield per cow and cost per 100 pounds of milk on the four farms.

between the very poor cow and the cow of medium quality than it is between the medium cow and the good cow. For instance, milk from cows producing from 3,001 to 4,000 pounds of milk per year costs 98 cents less per hundred pounds than milk from cows producing less than 3,000 pounds, while milk from cows producing over 8,000 pounds costs but 9 cents less per hundred than milk from cows producing from 7,001 to 8,000 pounds. The four herds in question were of mixed breeds, with Jerseys predominating. In the case of higher producing herds, or if returns were figured in.terms of butter fat rather than pounds of milk, different results might be expected. Often cows of only moderate production in pounds of milk yield good returns by reason of a high percentage of butterfat. 
TABLE XV.- Yearly savings in cost of milk production effected on the four farms by displacing low-yielding cows with higher-yielding cows, figured on the basis of data presented in Table XIV.

(a) DISPLACING A COW PRODUCING 3,000 POUNDS OR LESS.

\begin{tabular}{|c|c|c|c|c|c|}
\hline - & $\begin{array}{l}\text { Basis of classi- } \\
\text { fication (pro- } \\
\text { duction of milk } \\
\text { per cow). }\end{array}$ & $\begin{array}{l}\text { Arerage } \\
\text { produc- } \\
\text { tion. }\end{array}$ & $\begin{array}{l}\text { Cost per } \\
100 \\
\text { pounds. }\end{array}$ & $\begin{array}{c}\text { Cost of } \\
2,349 \\
\text { pounds. }\end{array}$ & $\begin{array}{l}\text { Saving } \\
\text { yearly in } \\
\text { cost per } \\
\text { cow. }\end{array}$ \\
\hline $\begin{array}{l}\text { Performance of cow displaced ............. } \\
\text { Comparative performance of better cows. }\end{array}$ & $\begin{array}{c}\text { Pounds. } \\
3,000 \text { or less. } \\
\left\{\begin{array}{r}3,001 \text { to } 4,000 \\
4,001 \text { to } 5,000 \\
5,061 \text { to } 6,000 \\
6,001 \text { to } 7,000 \\
7,001 \text { to } 8,000 \\
\text { Over } 8,000\end{array}\right.\end{array}$ & $\begin{array}{r}\text { Pounds. } \\
2,349.0 \\
3,645.0 \\
4,596.1 \\
5,450.0 \\
6,445.0 \\
7,513.5 \\
9,049.0\end{array}$ & $\begin{array}{r}\$ 3.57 \\
2.59 \\
2.29 \\
2.10 \\
1.86 \\
1.79 \\
1.70\end{array}$ & $\begin{array}{r}\$ 83.90 \\
60.84 \\
53.79 \\
49.33 \\
43.69 \\
42.05 \\
39.93\end{array}$ & $\begin{array}{r}\$ 23.06 \\
30.11 \\
34.47 \\
40.21 \\
41.85 \\
43.97\end{array}$ \\
\hline
\end{tabular}

(b) DISPLACING A COW PRODUCING 3,001 TO 4,000 POUNDS.

\begin{tabular}{|c|c|c|c|c|c|}
\hline $\begin{array}{l}\text { Performance of cow displaced............... } \\
\text { Comparative performance of better cows..... }\end{array}$ & $\left\{\begin{array}{r}3,001 \text { to } 4,000 \\
4,001 \text { to } 5,000 \\
5,001 \text { to } 6,000 \\
6,001 \text { to } 7,000 \\
7,001 \text { to } 8,000 \\
\text { Orer } 8,000\end{array}\right.$ & $\begin{array}{l}3,648.0 \\
4,596.1 \\
5,450.0 \\
6,445.0 \\
7,513.5 \\
9,049.0\end{array}$ & $\begin{array}{r}\$ 2.59 \\
2.29 \\
2.10 \\
1.86 \\
1.79 \\
1.70\end{array}$ & $\begin{array}{c}\text { Cost of } 3,648 \\
\text { pounds. } \\
\text { s9. } 4.48 \\
83.54 \\
76.61 \\
67.85 \\
65.30 \\
62.02\end{array}$ & $\begin{array}{r}\$ 10.94 \\
17.87 \\
26.63 \\
29.18 \\
32.46\end{array}$ \\
\hline
\end{tabular}

(c) DISPLACING A COW PRODUCING 4,001 TO 5,000 POUNDS.

\begin{tabular}{|c|c|c|c|c|c|}
\hline $\begin{array}{l}\text { Performance of cow displaced.............. } \\
\text { Comparative performance of better cows.. }\end{array}$ & $\left\{\begin{array}{r}4,001 \text { to } 5,000 \\
5,001 \text { to } 6,000 \\
6,001 \text { to } 7,000 \\
7,001 \text { to } 8,000 \\
\text { Orer } 8,000\end{array}\right.$ & $\begin{array}{l}4,596.1 \\
5,450.0 \\
6,445.0 \\
7,513.5 \\
9,049.0\end{array}$ & $\begin{array}{r}\$ 2.29 \\
2.10 \\
1.86 \\
1.79 \\
1.70\end{array}$ & $\begin{array}{r}\text { Cost of } \\
4,596.1 \\
\text { pounds. } \\
\$ 105.04 \\
96.52 \\
85.49 \\
82.27 \\
78.13\end{array}$ & $\begin{array}{l}\$ 8.52 \\
19.55 \\
22.77 \\
26.91\end{array}$ \\
\hline
\end{tabular}

(d) DISPLACING A COW PRODUCING 5,001 TO 6,000 POUNDS.

\begin{tabular}{|c|c|c|c|c|c|}
\hline $\begin{array}{l}\text { Performance of cow displaced............ } \\
\text { Comparative performace of hetter cows.. }\end{array}$ & $\left\{\begin{array}{r}5,001 \text { to } 6,000 \\
6,001 \text { to } 7,000 \\
7,001 \text { to } 8,000 \\
\text { Orer } 8,000\end{array}\right.$ & $\begin{array}{l}5,450.0 \\
6,445.0 \\
7,513.5 \\
9,049.0\end{array}$ & $\begin{array}{r}\$ 2.10 \\
1.86 \\
1.79 \\
1.70\end{array}$ & $\begin{array}{c}\text { Cost of } 5,450 \\
\text { pounds. } \\
\text { \$11.4. } \\
101.37 \\
97.56 \\
92.65\end{array}$ & $\begin{array}{r}\$ 13.05 \\
16.86 \\
21.77\end{array}$ \\
\hline
\end{tabular}

(e) DISPLACING A COW PRODUCING 6,001 TO 7,000 POUNDS.

\begin{tabular}{|c|c|c|c|c|c|}
\hline $\begin{array}{l}\text { Performance of cow displaced ............ } \\
\text { Comparative performance of better cows. }\end{array}$ & $\left\{\begin{array}{r}6,001 \text { to } \gamma, 000 \\
7,001 \text { to } 8,000 \\
\text { Over } 8,000\end{array}\right.$ & $\begin{array}{l}6,445.0 \\
7,513.5 \\
9,049.0\end{array}$ & $\begin{array}{r}\$ 1.86 \\
1.79 \\
1.70\end{array}$ & $\begin{array}{c}\text { Cost of } 6.445 \\
\text { pounds. } \\
\text { s120.03 } \\
115.37 \\
109.57\end{array}$ & $\begin{array}{r} \\
\\
\ldots \ldots+. .66 \\
\$ 10.46\end{array}$ \\
\hline
\end{tabular}

From the standpoint of economic milk production it would seem that the easiest step in the building up of a poor dairy herd is relatively the most profitable. Certainly the step from the poor cow to the cow of medium capacity is the one which promises the largest dividends on a modest expenditure of money and effort. In this connection the reader should study Table XV, which shows the gains resulting from progressively displacing a low-yielding cow with 
a better one. In these particular herds for every 7,000-pound cow that displaced a 3,000-pound cow there was an annual gain of over $\$ 40$, while for every 8,000-pound cow which displaced a 7,000-pound cow there was a gain of about $\$ 5$. From the foregoing it will be seen that the dairyman with limited capital need not be discouraged, as it is practicable for him to build up a highly productive and profitable herd.

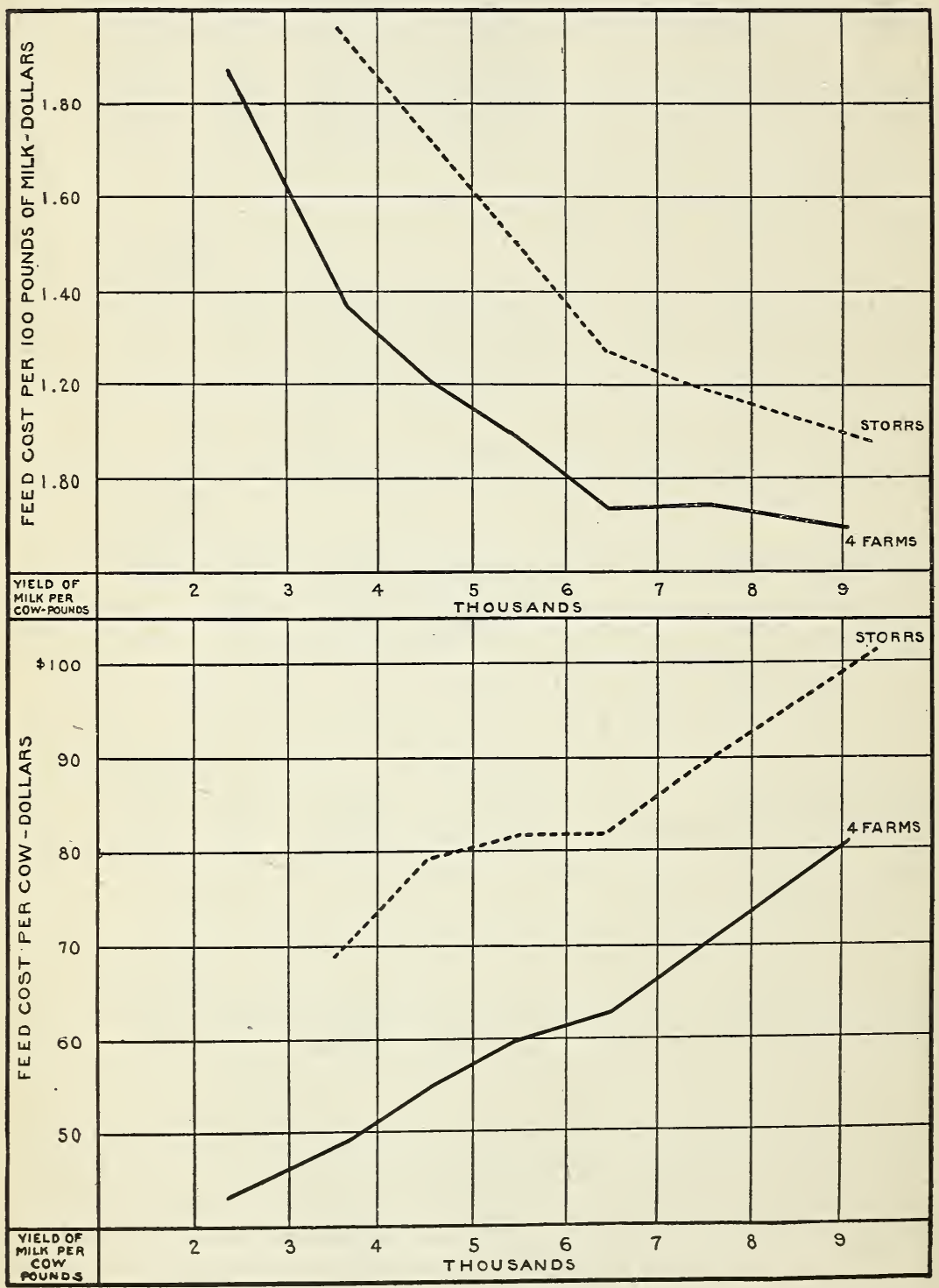

Fig. 8.-Data from the four farms and from Connecticut (Storrs) Agricultural Experiment Station. Upper: Relation between feed cost per 100 pounds of milk and production per cow. Lower: Relation between feed cost per cow and production per cow. 
This result is in keeping with common experience both with animals and crops, namely, that the greatest savings are achieved in changing from the very poorest animals or crops to those of medium production or better. ${ }^{1}$

Most of the cows producing less than 4,000 pounds in these herds were heifers. This illustrates a factor of economic importance connected with maintaining the standard of the herd by the introduction of heifers. Normally, heifers do not produce as much as mature cows. Moreover, many heifers, even though carefully selected, do not measure up to expectations and must be discarded. As a result, even in the most efficiently managed herds, the production from heifers is comparatively low, and the cost per unit of product relatively high. In connection with the discussion of this topic it is of interest to note the relative feed cost of cows on these four farms according to their milk production and to compare the same groups in their relation to the feed cost per 100 pounds of milk. These comparisons are made in graphic form in figure 8, which also includes curves constructed from records published by the Connecticut (Storrs) Agricultural Experiment Station. ${ }^{2}$ There were no cows in the station herd that produced less than 3,000 pounds. Owing to higher prices, the actual feed cost per cow and per unit of product was greater for the cows of each group in the station herd. The data from the four farms show that it costs more to keep a cow that gives a high yield of milk than one giving a low yield. However, within the limits of production shown by these cows, the profits from the high-producing animals are greater, because the increased cost of keeping a cow is not in proportion to increase in yield. This results in a lower unit cost for the product and a greater margin of profit, both per unit and per cow. These data emphazise the fact that the quality of the individual cow is a highly important factor in the cost per unit of product.

\section{SUMMARY.}

While the results derived from the cost records from the four farms in question may be said to be strictly applicable only to the farms upon which the studies were made, nevertheless they are representative of certain types of dairying, and the fundamental facts developed in studying them will be of considerable practical value to all milk producers and especially valuable to those operating under similar conditions.

From the information on these four farms there appears to be a fairly uniform relationship between various items entering into the cost of milk production according to the type of dairying followed.

1 "It is both easier and more profitable to inerease *** a small product per cow than a large one."-Dept. Bul. 341 .

2 See c, p. 34 . 
The feed cost on these farms seems to approximate 50 per cent of the total cost of keeping a cow where the cows depended on pasture with little or no grain during the pasture season; whereas, feed cost approximated 60 per cent on the farms where the pasture is limited and a grain ration is fed throughout the year.

Labor, the second important item in the cost of producing milk, amounted to approximately one-fourth of the total cost of keeping a cow.

All other items, including charges for shelter, use of equipment, use of bull, interest, depreciation, miscellaneous supplies, and a share of overhead expenses, amounted to approximately one-fourth the total cost of keeping a cow. The credits other than milk, including the value of calf, manure, and minor items, did not equal the miscellaneous costs other than feed and labor.

Though it cost more to keep a cow that gives a high yield than one giving a low yield, the unit cost of the milk produced fell as the yield per cow rose. This decrease in the cost of milk per pound was much greater in the step from the poor cow to the cow of fair quality than in the step from the fairly efficient cow to the good cow or to the exceptional cow. Thus, from the standpoint of economic milk production, it appears that the first step in building up a poor dairy herd (that is, replacing scrubs with grades) is not merely the easiest step but also the one which promises the most for a given expenditure of money and labor.

The actual cost of keeping the cows varied from year to year on the different farms as well as on the same farm, yet the ratio between each item and the total cost was apparently quite uniform where a similar method of management was followed.

(a) Rasuussen, Fred.

\section{LITERATURE CITED.}

1913. Cost of milk production. N. H. Col. and Exp. Sta. Ext. Bul. 2.

(b) Lindsey, J. B.

1913. Record of the station dairy herd and the cost of milk production. Mass. Agr. Exp. Sta. Bul. 145.

(c) Trueman, J. M.

1912. Records of a dairy herd for five years. Conn. (Storrs) Agr. Exp. Sta. Bul. 73.

(d) Warren, G. F.

1914. Some important factors for success in general farming and in dairy farming. N. Y. Cornell Agr. Exp. Sta. Bul. 349; Reasons for larger profits on diversified farms, pp. 691-693.

(e) Haecker, T. L.

1913. Feeding dairy cows. Minn. Agr. Exp. Sta. Bul. 130, p. 37.

( $f$ ) Frandsen, J. H., and Haecker, A. L.

1914. Dairy herd records for fourteen years. Nebr. Agr. Exp. Sta. Bul. 139.

(g) Spillman, W. J., Dixon, H. M., and Billings, G. A.

1916. Farm management practice of Chester County, Pa. U. S. Dept. Agr. Bul. 341. 


\section{DATA ON COST OF PRODUCING MILK ARE ALSO REPORTED IN THE FOLLOWING} PUBLICATIONS.

LARSON, C. W.

1916. Milk production cost accounts, principles and method. New York. Columbia University Press.

Thompson, A. L.

1915. Cost of producing milk on 174 farms in Delaware County, New York. N. Y. Cornell Agr. Exp. Sta. Bul. 364.

Hopper, H. A., and Robertson., F. E.

1915. The cost of milk production. N. Y. Cornell Agr. Exp. Sta. Bul. 357.

Henry, W. A., and Morrison, F. B.

1916. Feeds and Feeding. Ed. 16, 691 pp. Madison, Wis. "Feed required COOPER, T. P. by cow and cost of producing milk and fat." pp. 395-397.

1909. The cost of producing Minnesota dairy products, 1904-1909. Minn. Agr. Exp. Sta. Bul. 124, U. S. Dept. Agr. Bureau of Statistics Bul. 88.

1898-1915. Cost of producing milk. In Ann. Reports, N. J. Agr. Exp. Sta., 1897, pp. $177-180 ; 1898$, pp. 215-217; 1899, pp. 257-260; 1900, pp. 295-298; 1901, pp. $287-290$; 1902, pp. $312-315$; 1903, pp. 374-377; 1904, pp. 407-410; 1906, pp. 298-302; 1907, pp. 79-82; 1909, pp. 73-76; 1910, pp. 64-67; 1912, pp. 194-199; 1913, pp. 314-318; 1914, pp. 154-168.

1915. The cost of milk production. Hoard's Dairyman, vol. 48, pp. 669-670, Jan. 1.

ADDITIONAL COPIES

OF THIS PUBLICATION MAY BE PROCURED FROM THE SUPERINTENDENT OF DOCUMENTS GOVERNMENT PRINTING OFFICE

WASHINGTON, D. C.

$$
\text { AT }
$$

5 CENTS PER COPY 
